\title{
Climate-driven episodes of dune mobilization and barrier growth along the central coast of Portugal
}

\author{
SUSANA COSTAS ${ }^{1 *}$, PEDRO BRITO $^{1}$, DUNCAN FITZGERALD $^{2} \&$ RONALD GOBLE $^{3}$ \\ ${ }^{1}$ Laboratório Nacional de Energia e Geologia, Estrada da Portela-Bairro de Zambujal, \\ Apartado 7586-Alfragide, 2610-999 Amadora, Portugal \\ ${ }^{2}$ Boston University Earth \& Environment, 685 Commonwealth Avenue, Boston, MA 02215, USA \\ ${ }^{3}$ University of Nebraska-Lincoln, 214 Bessey Hall, Lincoln, NE 68583-0340, USA \\ *Corresponding author (e-mail: susana.costas@lneg.pt)
}

\begin{abstract}
Here, we explore the evolution of the coastal stretch between Mira Beach and Quiaios Beach in Portugal to understand how it adapted to climatic oscillations. To accomplish this, we integrate subsurface radar images, and sedimentological and chronological data, of the emerged coastal barrier. Our results show the installation and progradation of a stable barrier anchored to transgressive dunes 400 years ago. This is just the last pulse of barrier growth within a complex approximately 5000 year-long history of shoreline stability/instability. Episodes of inland dune mobility have been related to instabilities in the beach sediment budget driven by enhanced storminess and wave rotation around 4.25 and $1.14 \mathrm{ka}$ ago. Conversely, lagoonal deposits documented in the literature suggest periods of relative barrier stability and growth around 4.3 and $2.7 \mathrm{cal} \mathrm{ka} \mathrm{BP}$. Wave and wind climate variability are driven by shifts in one of the major modes of atmospheric circulation in the North Atlantic, the North Atlantic Oscillation (NAO). Episodes of persistent positive mode of the NAO related to barrier growth and enhanced longshore sediment transport; those of persistent negative mode contributed to instabilities in the beach sediment budget and aeolian activity by enhancing storminess, but reduced effective longshore sediment transport.
\end{abstract}

This paper explores the effects of sea level, climatic variability and possible human interferences on the evolution of a large coastal barrier system located in the central coast of Portugal. This has been achieved by establishing present coastal morphology and sediment characterization, the internal structure of the deposits with ground penetrating radar (GPR) and sediment cores, and age determination of deposits by optically stimulated luminescence (OSL).

Coastal barriers are depositional elements that comprise approximately $15 \%$ of the world's coastlines (FitzGerald et al. 2008). Their formation coincides with the worldwide sea-level stabilization reached in the mid-Holocene. This stabilization, coupled with an abundant sand supply from the recently inundated continental shelf, provided a window of opportunity for barrier growth. Hypotheses concerning the formation of barrier islands have been proposed for more than 150 years. They are supposed to initiate as offshore bar accretion (Beaumont 1845), or spit progradation (Gilbert 1890), or submergence or mainland detachment of coastal ridges (Hoyt 1967). More recently, numerical models have been proposed to explain barrier evolution in response to sea-level changes (Cowell et al. 1995; Stolper et al. 2005; Masetti et al. 2008). These models attempt to show the processes involved in the landwards migration of barriers during the Holocene transgression in order to evaluate how the barriers will respond to future changes in sea level and climate.

The presence of back-barrier deposits outcropping seawards from the islands has been interpreted as evidence of the landwards translation in the recent geological past (Evans et al. 1985; Brooks et al. 2003). These deposits have also been interpreted as evidence of in-place drowning of barrier islands during their landwards retreat and suggested discontinuous or stepwise barrier retreat (Rampino \& Sanders 1981). Modelling different scenarios of sea-level rise during the past 8000 years indicate that the rate of overwash and lagoonal deposition are critical for the survival of the barrier islands under past sea-level oscillations (Masetti et al. 2008). Model simulations show that barrier island translation was not uniform, but occurred sporadically as a function of bottom topography (lagoon depth and slope) and sediment availability (Masetti et al. 2008). In this scenario, prehistoric barriers might have been present during periods of lower sea level, but they formed and disappeared without significant onshore migration and re-establishment.

Along the Portuguese coast, there is little evidence of landwards translation of coastal barriers 


\section{S. COSTAS ET AL.}

during the last marine transgression, with the exception of the reconstruction made by Teixeira et al. (2005) for the last 9000 years in the southern coast. Conversely, there are numerous references concerning well-documented archives of estuarine infilling and lagoon onset since the Late Glacial (Cearreta et al. 2003). These examples establish marine inundation of estuaries as early as $10 \mathrm{ka}$ BP. However, in most cases, barrier formation was apparently initiated only approximately $5.5 \mathrm{ka} \mathrm{BP}$, as inferred by the shift from open to barrierrestricted estuaries (Naughton et al. 2007) or lagoons (Cearreta et al. 2003). Examination of the sedimentary record within lagoons documents their progressive infilling under low-energy, restricted conditions, with episodes of increased marine influence due to barrier breaching (Bao et al. 1999; Cearreta et al. 2003). Coastal lagoons with infilling histories extending from the mid-Holocene to the Present are found associated with welded barriers enclosing drowned valleys along the central and southern sectors of the western Portuguese coast (Cearreta et al. 2003; Cabral et al. 2006).

Alternatively, evidence of ephemeral lagoons and landwards shoreline translation during the mid-late Holocene have been reported along the north-central coast of Portugal (Granja et al. 1996, 2008, 2010; Granja 1999, 2000; Bernardes \& Rocha 2007; Danielsen et al. 2012). These results suggest a scenario of barrier evolution for highenergy and linear coasts characterized by landwards shoreline translation since the mid Holocene, when sea level reached its present position (Vis et al. 2010a; Leorri et al. 2013). To further investigate the recent evolution of these environments and understand the major drivers behind it, we examine the coastal segment between Mira Beach and Mondego Cape. At present, a sandy barrier extends from Espinho to Mondego Cape enclosing the Aveiro lagoon (Fig. 1a). Most of this coastal segment, namely the sector between Espinho and Mira Beach, experiences severe erosion and shoreline retreat, resulting in lagoonal sediments (radiocarbon dated at c. 2 cal ka BP) cropping out along the beach face (Granja \& De Groot 1996; Bernardes \& Rocha 2007). Downdrift, the coastal section between Mira Beach and Mondego Cape consists of a coastal barrier attached to a transgressive dunefield without a clear indication of shoreline retreat (Fig. 1b). Previous work found evidence for the existence of a $1 \mathrm{~km}$-wide lagoon between Quiaios Beach and Tocha Beach (Fig. 1b) around 4.1 cal ka BP (Danielsen et al. 2012). The authors suggested that the lagoon was fully infilled by aeolian sand some time between 3.5 and $1.5 \mathrm{ka} \mathrm{BP}$ following human deforestation in the region. However, the drivers, age and the source of this sand which promoted lagoon infilling and the development of the present barrier still remains not fully resolved. Here, we explore the subsurface architecture of the transgressive dunes and attached barrier system to understand the recent evolution of this region,

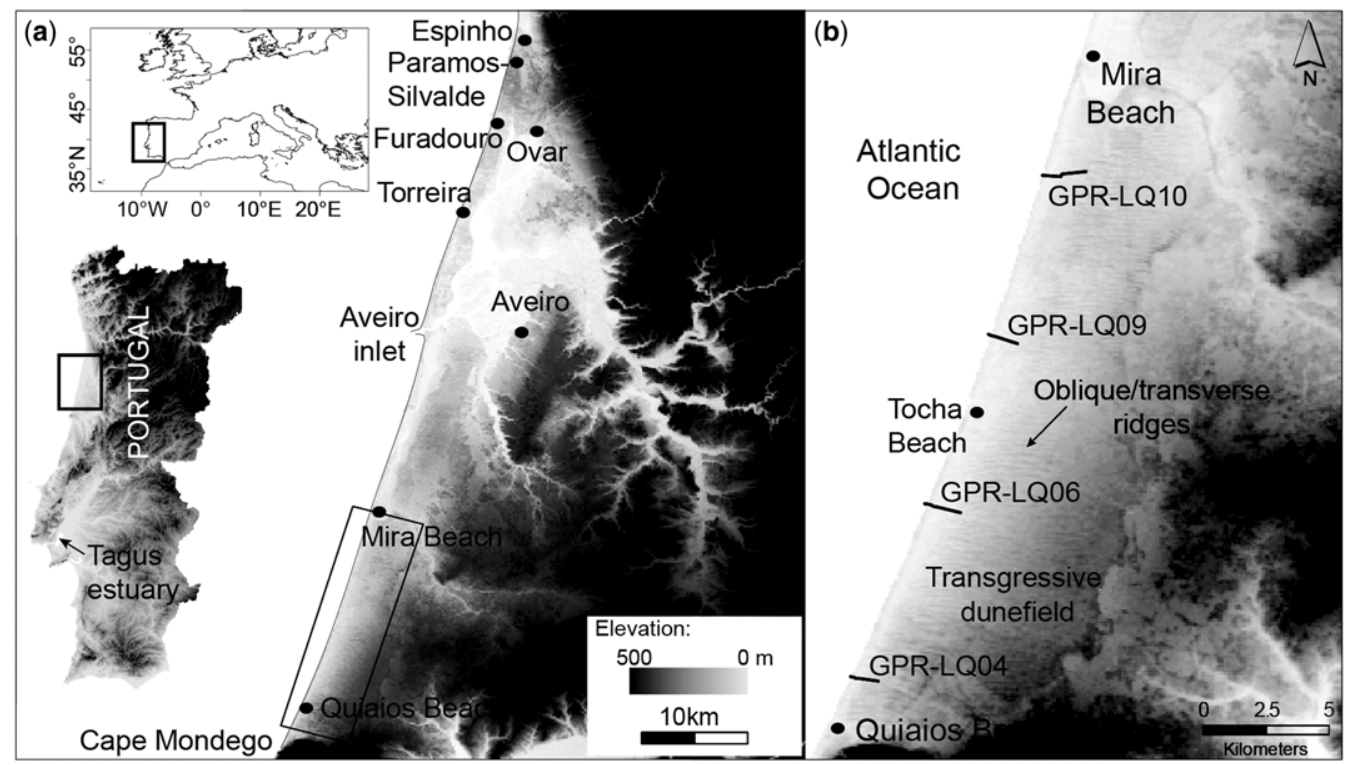

Fig. 1. Location of the study area in the central coast of Portugal (a) and location of the collected GPR lines (b). Digital terrain model provided by the Instituto Geográfico Português. 
framed in a high-energy transgressive coast. The results from this work contribute to our understanding of the major stabilization-destabilization pulses that apparently controlled the recent evolution of the Portuguese coast, as well as the nature of their driving forces.

\section{Regional settings}

The study area is located along the central coast of Portugal and consists of a $27 \mathrm{~km}$-long sandy highenergy coast, extending between Mira Beach and Cape Mondego (Fig. 1a, b). The coast is mesotidal, reaching $4 \mathrm{~m}$ of tidal range during spring tides. This shore segment is part of a linear sandy coast that extends from Espinho to Mondego, enclosing the coastal lagoon of Aveiro (Fig. 1a). The coastline is oriented NNE-SSW and consists of a beach-foredune system exposed to high-energy waves generated in the North Atlantic, with a mean annual significant wave height of $2-3 \mathrm{~m}$ and a significant wave period of 10-12 s (Costa 1994). The dominant wave direction is from the northerly quadrant, although southwesterlies prevail during winter storms. Extreme storm wave conditions for the period between 1979 and 1992 had a mean annual significant wave height of $7.3 \mathrm{~m}$, and wave heights of $9.5 \mathrm{~m}$ reach the coast with a return period of 10 years (Carvalho \& Capitão 1996). This wave regime produces a net southerly longshore transport of sediment, with the average rate ranging between $1 \times 10^{6}$ and $2 \times 10^{6} \mathrm{~m}^{3} \mathrm{a}^{-1}$ (Barata et al. 1996). The windfield regime in the region of Aveiro is dominated by north and northwesterly winds. However, during winter this pattern becomes more variable, with an increasing importance of south and southeasterlies (Serviço Meteorológico Nacional 1974).

It is widely accepted that the sediment source to the coast under natural conditions was essentially fluvial and has significantly reduced since the early twentieth century as a result of human interventions, such as the construction of dams and coastal armouring (Oliveira et al. 1982; Andrade et al. 2002). As the natural sand supply diminished, coastal systems developed an erosional trend that has been increasing in intensity and extent since that time (EUROSION 2003). Although the effect of coastal armouring is clearly detected in some segments of the coast, particularly downdrift of the Aveiro inlet jetty, the effect of dam construction is not clear and the sources of sediment to the coast remains an open question. Granja (2000), for example, found that the nature of the sediments trapped by the recently built dams does not correspond to that of the beaches, suggesting that sedimentary deposits or rocky outcrops along the adjacent shelf could be major sources.
The coastal segment between Espinho and Mondego is characterized by a wide inner shelf accounting for the accommodation of large volumes of Plio-Pleistocene and Holocene sediments. Transgressive coastal dunes deposited approximately $30 \mathrm{ka}$ BP to the south of Espinho constitute the anchoring point of a barrier spit that extends to Mira Beach confining the Aveiro estuary. South of Mira Beach, the barrier attaches to a transgressive dunefield that extends inland from the coast for $7 \mathrm{~km}$ (Fig. 1b). The variable wind regime and sand supply have produced a complex dunefield. The most common and best-defined aeolian features are elongated ridges around $1 \mathrm{~km}$ long, with a spacing of $200 \mathrm{~m}$. These features were interpreted by Almeida (2012) as oblique dunes resulting from the combined effect of winds blowing from diverse and almost opposite directions. By contrast, other studies have classified the dunefield as dominated by transverse dunes (Noivo 1996) or elongated hairpin and complex parabolic forms with occasional crescentic shapes (Clarke \& Rendell 2006) produced by the dominant northwesterlies. Pulses of aeolian activity within the transgressive dunefield were synchronous with climatic degradation during the Younger Dryas (Danielsen et al. 2012), and between 9.7 and $8.2 \mathrm{ka}$ (Clarke \& Rendell 2006). Parabolic dunes found in the region between the foredune and the elongated features have yielded ages (OSL age determinations made in 1995) between 1145 and 620 years (Granja 1996). The last major pulse of aeolian activity in the region was related to the mobilization of the elongated dunes during the Little Ice Age between AD 1770 and AD 1905 (Clarke \& Rendell 2006).

Evidence from lagoonal deposits suggests the existence of former coastal barriers. Lagoonal deposits were found and radiocarbon dated in Silvalde-Paramos and Furadouro-Torreira as $4920 \pm 105 \mathrm{ka}$ BP (Granja 1999), $2310 \pm 90 \mathrm{ka}$ BP (Granja et al. 1996) and 1997 cal a BP (Bernardes \& Rocha 2007) (Fig. 1a). These lagoonal deposits crop out in the present foreshore and imply a former shoreline seawards of the present by at least 2 cal ka BP (Granja 2002; Bernardes \& Rocha 2007). In addition, Danielsen et al. (2012) found evidence of lagoonal deposits dated at about $4.3 \mathrm{cal} \mathrm{ka} \mathrm{BP}$ in the southernmost part of the coastal segment. It apparently was filled with aeolian sediments some time between 3.5 and 1.5 cal ka BP.

Analyses of the recent evolution of the Aveiro Lagoon based on old maps document an open estuary during the tenth century (Girão 1941; Abecasis 1954). This was progressively enclosed by the growth of a barrier spit extending from Ovar to Mira Beach (Fig. 2) and coincident with the southwards migration of an inlet between AD 1200 and 
AD 1756 (Abecasis 1954). Alternatively, OSL ages from beach sediments to the south of Torreira and to the north of Tocha Beach yielded ages around AD 850 and $\mathrm{AD} 450$, respectively (Granja 2000), suggesting barrier sediments older than indicated on historical maps. Finally, an inlet was artificially opened and fixed at its present position in 1808 . The jettied inlet is an obstacle to the longshore sediment transport and sediment bypass causing severe downdrift erosion. Analyses of recent shoreline changes between Aveiro inlet and Mondego Cape document a significant shoreline retreat downdrift of the inlet, and the seawards advance of the coastal segment between Mira Beach and Mondego Cape (Menezes 2011).

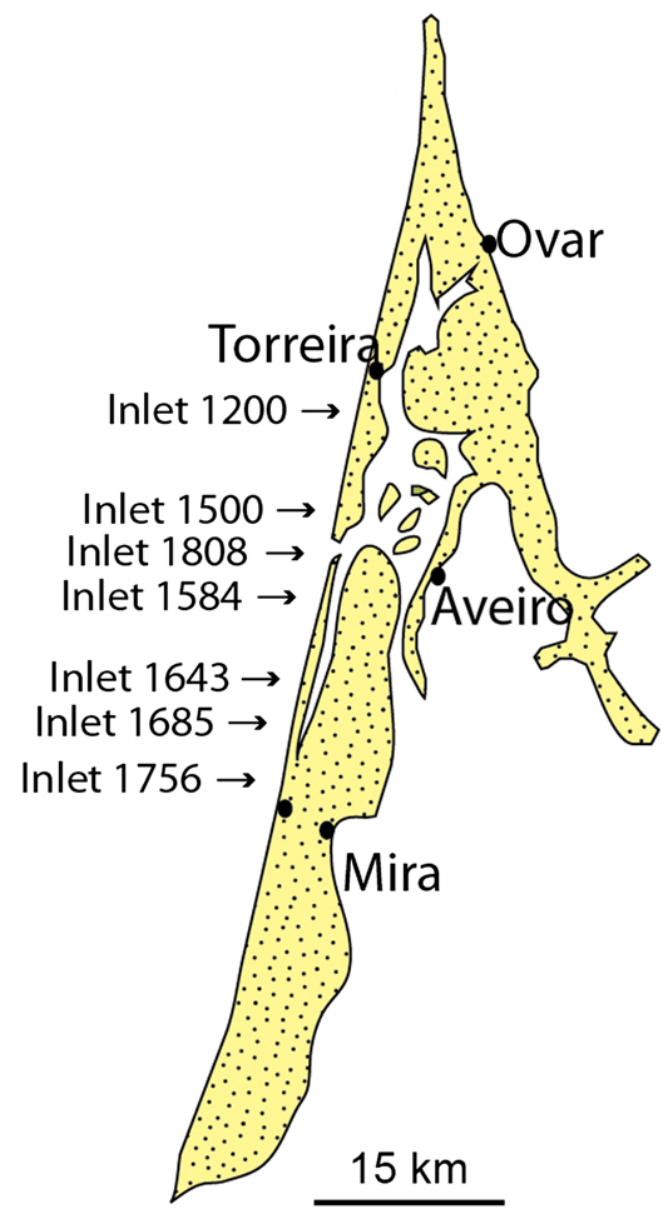

Fig. 2. Evolution of the lagoon of Aveiro showing the southwards elongation of the barrier spit isolating the ancient bay from the sea (after Abecasis 1954). Numbers indicate years AD.

\section{Methods}

\section{Present-day coastal system}

Topographical surveys using a RTK-GPS (Real Time Kinematics-Global Positioning System) were carried out to characterize the morphology of the present beach, and its contact with the adjacent foredune along two beach profiles between Mira Beach and Quiaios Beach. Positioning data were collected using the projected coordinate reference system ETRS89/Portugal TM06 and elevations referenced to mean sea-level (MSL); Cascais vertical datum. During the surveys, the elevation marks left by maximum water levels in the beach were recorded as indicators of maximum wave run-up and, thus, as indicators of the transition between the beach and the adjacent foredune. Surface sediment samples were collected along the beach profile.

\section{Subsurface images and sediments}

The spatial delineation between the coastal barrier system and the adjacent trangressive dunefield was determined with a Ground Penetrating Radar (GPR) system. Images of the subsurface were acquired using an Ingegneria Dei Sistemi-Ground Penetrating Radar (IDS-GPR) system RIS MF HiMod \#1 equipped with a dual-frequency antenna (200 and $600 \mathrm{MHz}$ ). GPR transects were run to resolve sedimentary facies within the beach profile and the transition area towards the adjacent foredune (Bristow \& Pucillo 2006). In addition, GPR was used to reconstruct the prograding coasts by mapping subsurface scarps and accretionary units, which in turn represent the morphological response of past erosional events and subsequent depositional phases, respectively (Buynevich et al. 2007). A total of four cross-shore GPR profiles $1.5 \mathrm{~km}$ long, spaced around $7 \mathrm{~km}$ apart, were surveyed from the present upper beach into the transgressive dunefield (Fig. 1b). Maximum penetration (depth around $6 \mathrm{~m}$ ) was achieved using the $200 \mathrm{MHz}$ antenna. Low penetration was due to the attenuation of the electromagnetic waves by the presence of salt-water infiltrations in the beach. Inland of the foredune ridge, signal attenuation was related to the high dielectric constant of water molecules (Daniels 2005).

The GPR was synchronized to a RTK-GPS system in order to obtain the topographical information for static correction during the processing of the radargrams. Raw data were processed using the program package Reflex-Win Version 5.0.5 by Sandmeier Software. Processing included timezero drift, application of filters and gains, velocity profile estimate, migration and static corrections. An average subsurface velocity of $0.16 \mathrm{~m} \mathrm{~ns}^{-1}$ 
was estimated using the interactive hyperbolaadaptation method and is a typical velocity for dry sand. Interpretation of geophysical data was completed with lithological data from cores collected using a TESS-1 suction core (Méndez et al. 2003). Nine suction cores ( $5 \mathrm{~m}$ in length) of beach and aeolian sand were collected along two cross-shore GPR lines (Fig. 3b, c), and split for core description and sampling for macroscopical and textural analysis.

\section{OSL dating}

Results from GPR and sediment cores were integrated in order to select the best locations to date the stratigraphic units. The samples were collected with the suction core in order to reach the selected depths. The cores were retrieved in dark grey and opaque PVC tubes to avoid exposure of the sediments to sunlight; hence, suitable for luminescence dating. Once at the surface, a segment of $35 \mathrm{~cm}$ centred at the desirable depth was cut off and sealed. The samples were optically stimulated luminescence (OSL) dated at the University of Nebraska-Lincoln, Luminescence Geochronology Laboratory.

Sample preparation was carried out under amber-light conditions. Samples were wet sieved to extract the 250-355 $\mu \mathrm{m}$ fraction, and then treated with $\mathrm{HCl}$ to remove carbonates and $\mathrm{H}_{2} \mathrm{O}_{2}$ to remove organics. Quartz and feldspar grains were extracted by flotation using a $2.7 \mathrm{~g} \mathrm{~cm}^{-3}$ sodium polytungstate solution, then treated for $75 \mathrm{~min}$ in $48 \% \mathrm{HF}$, followed by $30 \mathrm{~min}$ in $47 \%$ $\mathrm{HCl}$. The sample was then resieved and the $<250 \mu \mathrm{m}$ fraction discarded to remove residual feldspar grains. The etched quartz grains were mounted on the innermost 2 or $5 \mathrm{~mm}$ of $1 \mathrm{~cm}$ aluminium disks using Silkospray. Chemical analyses were carried out using inductively coupled plasmamass spectrometry (ICP-MS) and inductively coupled plasma-atomic emission spectrometry (ICP-AES) by Activation Laboratories Ltd, Ancaster, Ontario, Canada. Three samples (UNL3522, UNL3527 and UNL3530) were also analysed by high-resolution gamma spectrometry at the

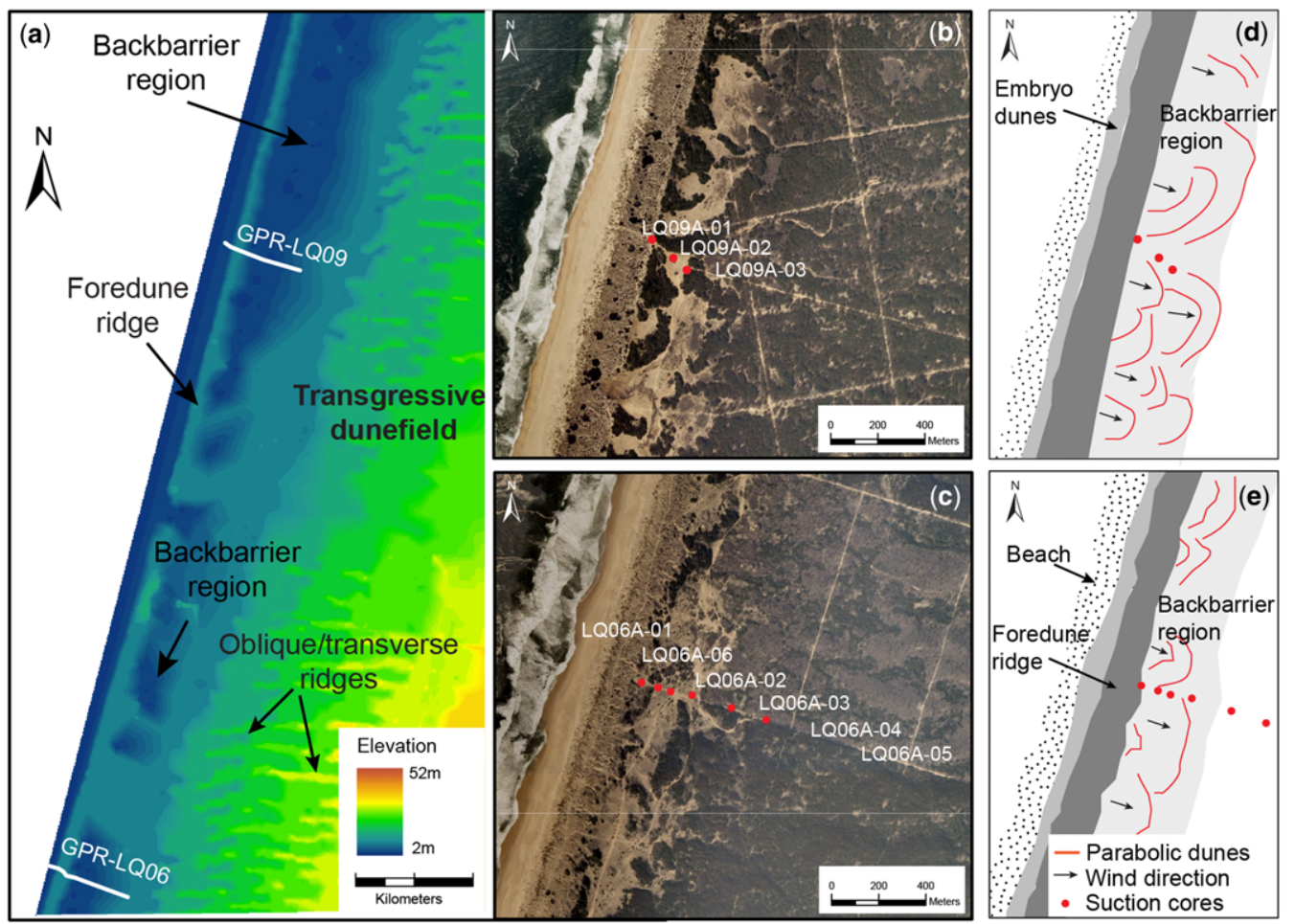

Fig. 3. (a) Digital terrain model (data provided by the Instituto Geográfico Português) of a part of the study area indicating the major morphological features present in the coastal fringe, and location of the GPR transects. (b) \& (c) Aerial photographs with the location of the sediment cores collected in the backbarrier sector along transects GPR-LQ09 and GPR-LQ06, respectively. (d) \& (e) Synthetic morphological interpretation of the aerial photographs presented in (b) \& (c), respectively. 


\section{S. COSTAS ETAL.}

University of Nebraska-Lincoln. $\mathrm{K}_{2} \mathrm{O}, \mathrm{U}$ and $\mathrm{Th}$ values from the two methods are within $2 \sigma$, and the gamma spectra show no evidence of radioactive disequilibrium. Dose rates were calculated using the method of Aitken (1998) and Adamiec \& Aitken (1998). Dose-rate conversion factors are from Guerin et al. (2011) and attenuation coefficients from Brennan (2003). The cosmic contribution to the dose rate was determined using the techniques of Prescott \& Hutton (1994).

Optically stimulated luminescence analyses were carried out on Ris $\varnothing$ Automated OSL Dating System Model TL/OSL-DA-15B/C and TL/ OSL-DA-20 readers, equipped with blue and infrared diodes, using the single aliquot regenerative dose (SAR) technique (Murray \& Wintle 2000). All equivalent dose $\left(D_{\mathrm{e}}\right)$ values were determined using the Central Age Model (Galbraith et al. 1999), unless data analysis indicates partial bleaching, in which case the Minimum Age Model (Galbraith et al. 1999) was used. Preheat and cutheat temperatures were based on preheat plateau tests between 180 and $280^{\circ} \mathrm{C}$. Preheat and cutheats of $240{ }^{\circ} \mathrm{C} / 10 \mathrm{~s}$ and $220^{\circ} \mathrm{C} / 0 \mathrm{~s}$, and $200^{\circ} \mathrm{C} / 10 \mathrm{~s}$ and $180^{\circ} \mathrm{C} / 0 \mathrm{~s}$ were used for older and younger samples, respectively. Dose-recovery and thermal transfer tests were performed (Murray \& Wintle 2003). Growth curves were examined to determine whether the samples were below saturation $\left(D / D_{\mathrm{o}}\right.$ $<2$ : Wintle \& Murray (2006)). Optical ages are based on a minimum of 50 aliquots (Rodnight 2008). Individual aliquots were monitored for insufficient count rate, poor-quality fits (large error in $D_{\mathrm{e}}$ ), poor recycling ratio, strong medium v. fast component (Durcan \& Duller 2011), and detectable feldspar. Aliquots deemed unacceptable based upon these criteria were discarded from the data set prior to averaging. Averaging was carried out using the Central Age Model (Galbraith et al. 1999) unless the $D_{\mathrm{e}}$ distribution (asymmetric distribution; skew $>2 \sigma_{\mathrm{c}}$ : Bailey \& Arnold 2006) indicated that the Minimum Age Model (Galbraith et al. 1999) was more appropriate.

\section{Results}

\section{Present-day coastal system}

The coastal system consists of three major components: the present beach and the foredune ridge; a topographical depression referred here as the backbarrier region; and the transition towards the inland transgressive dunefield.

The present-day beach is characterized by a multibarred intermediate beach (Ferreira 1998). The subaerial beach profile shows a steep foreshore of about $5^{\circ}$. The high elevation of the berm $(5 \mathrm{~m}$ above MSL: Fig. 4a) is the result of high wave energy impacting this coast, which contributes locally to high mean water levels. The backshore region of the beach is wide, extending for $30 \mathrm{~m}$. Surface sediments collected within the immersed beach document the presence of two well-defined populations of sediment. The major component consists of coarse- to medium-grained sand, whereas a secondary component can be found in the upper part of the foreshore and berm resulting from the concentration of pebbles at the high-tide water mark. The pebbles consist of rounded lithic fragments and unbroken shells of bivalves that lived in the offshore (Loripes lacteus). The transition between the backshore and the adjacent foredune can locally be abrupt, marked by an erosive scarp (ranging from 0.5 to $2 \mathrm{~m}$ ) or gradational through embryo dunes.

The foredune ridge is around $200 \mathrm{~m}$ wide and consists of several secondary crests that gradually decrease in elevation inland. The highest crest reaches $14 \mathrm{~m}$ above MSL (Fig. $4 \mathrm{a}, \mathrm{b}$ ). Sediments collected within the foredune are characterized by a well- to moderately-sorted population of mediumgrained sand.

The backbarrier region is represented by a sandy, approximately $100 \mathrm{~m}$-wide depression paralleling the present shoreline (Figs $3 a$ \& $4 b$ ). The average elevation of the backbarrier region coincides with that of present beach berm $(5 \mathrm{~m}$ above MSL) and is frequently flooded as the water table rises during the wet season (winter). The backbarrier region contains evidence of past deflation, including the presence of parabolic dunes (Fig. 3d, e) and the concentration of coarse-grained sediments at the surface. The presence of large, entire shells and pebbles concentrated at the surface by deflation resembles the population of coarser sediments in the upper foreshore. Accordingly, the backbarrier region has been interpreted to have been part of a beach composed of sandy deposits OSL dated to about $1.5 \mathrm{ka}$ (Granja et al. 1996), and reworked shells radiocarbon dated between $2770 \pm 60$ and $2100 \pm 130$ a BP (Granja et al. 1996).

Inland of the low backbarrier region, there is a $300 \mathrm{~m}$-wide zone of poorly defined dunes advancing inland that constitute the westwards end of the ridges developed in the inland dunefield. This zone constitutes a transition towards the inland transgressive dunefield, which consists of $1 \mathrm{~km}$-long oblique/transverse ridges oriented west-east, and extends about $6 \mathrm{~km}$ inland (Fig. 1b). The ridge spacing is approximately $200 \mathrm{~m}$ and is up to $10 \mathrm{~m}$ high (Fig. 3a).

\section{Facies analysis}

Facies analysis involved integration of data from GPR surveys and from sediment cores collected to 

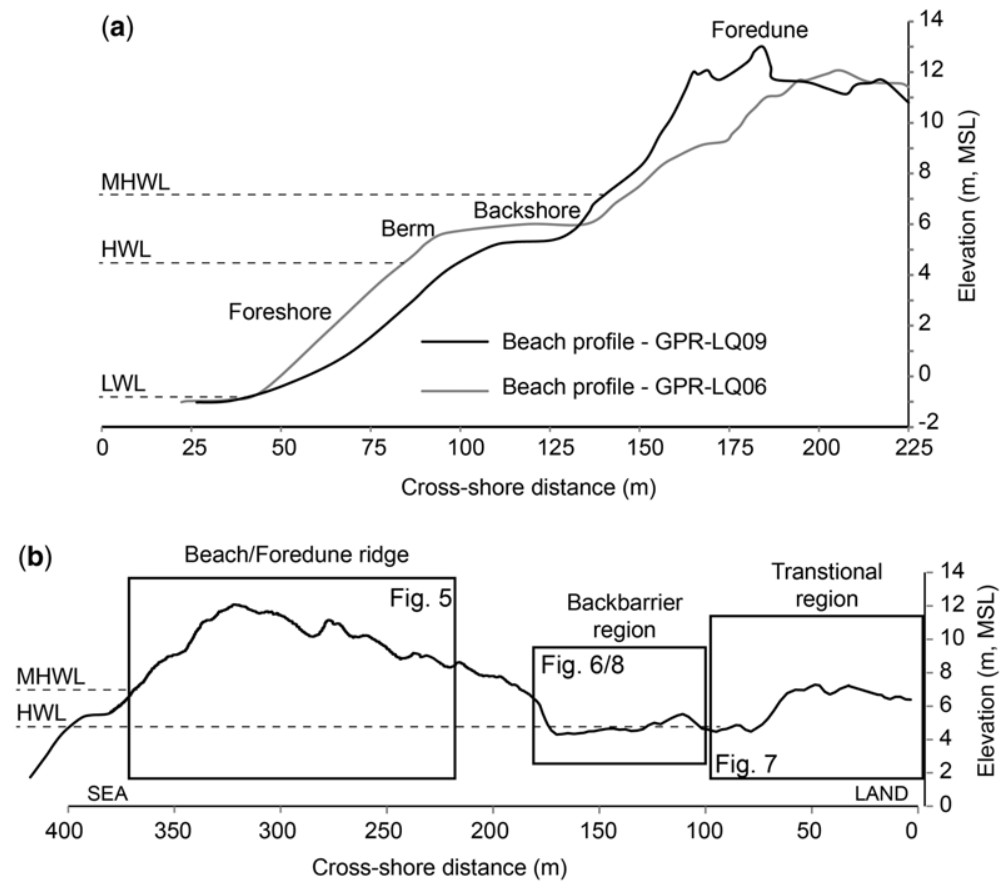

Fig. 4. (a) Present-day beach profiles representative of the analysed coastal segment. Beach profiles represent the seawards extension of profiles GPR-LQ06 and GPR-LQ09. The elevations of the maximum high water level (MHWL), high water level (HWL) and low water level (LWL) are indicated. (b) Typical cross-shore profile extending from the beach berm to the region of transition between the backbarrier and the inland dunefield.

ground truth the geophysical data. Classification of the internal reflection configurations is primarily related to their continuity, attitude and interval, using the terminology developed by Mitchum et al. (1977). Six radar facies (RF1-RF6) have been identified based on the configuration of the internal reflections and boundaries (Table 1). Interpretation of the radar facies was aided by the morphology and GPR signature of present-day coastal features, and by previous work carried out in similar environments (van Heteren et al. 1998; Bristow et al. 2000). Radar facies are described with the associated lithological characteristics and interpretation. Lithological facies were based on the characteristics of the collected sediment.

A horizontal-paired, strong reflection running across the foredune at approximately $3 \mathrm{~m}$ above MSL was interpreted as the water table associated with a subsurface freshwater aquifer (Fig. 5a). Saltwater intrusions are responsible for the shallowdepth reflection-free area at the seawards end of the foredune (Fig. 5a).

RF1. Biotopographical accumulation. Packages of RF1 were identified in the subsurface of the foredune ridge and consist of hummocky mounded clinoforms represented by high-amplitude and lowangle, discontinuous, concave and convex reflections extending up to $10 \mathrm{~m}$ (Fig. 5). Bristow et al. (2000) interpreted these deposits as accretionary mounds that formed around vegetation. Secondary crests in foredune rigde correspond to areas of concentrated RF1 in the radar record, suggesting that the sediment producing these facies was only deposited once the pioneer plants (Elymus arenarius) gave way to Marram (Ammophila arenaria) and heaths (Calluna vulgaris).

Sediment core LQ06A-01, collected in the foredune ridge (Fig. 3c), documents moderately wellsorted medium- to coarse-grained quartzose sands with mean grain sizes of around $0.5 \mathrm{~mm}$. Enriched horizons of heavy minerals, highly fragmented shells and the rest of roots have been observed within the sediment core.

RF2. Transgressive dunes. Packages of RF2 are dominated by sigmoidal reflections gently dipping landwards and extending up to $20 \mathrm{~m}$ (Figs $6 \& 7$ ). RF2 facies were interpreted as representing aeolian dunes migrating inland due to onshore winds. Radar packages of RF2 are commonly truncated by subhorizontal bounding surfaces resulting from 


\section{S. COSTAS ET AL.}

Table 1. Summary of the facies identified in the study area including their radar and sedimentological features

\begin{tabular}{|c|c|c|c|}
\hline Facies & Radar features & Lithology & Interpretation \\
\hline RF1 & $\begin{array}{l}\text { Hummocky mounded, } \\
\text { low-angle clinoforms }\end{array}$ & $\begin{array}{l}\text { Moderately well-sorted, medium- to } \\
\text { coarse-grained sand (mean } \\
0.5 \mathrm{~mm} \text { ). Horizons of heavy } \\
\text { minerals, fragmented shells }\end{array}$ & $\begin{array}{l}\text { Biotopographical } \\
\text { accumulation }\end{array}$ \\
\hline RF2 & $\begin{array}{l}\text { Sigmoidal reflections gently } \\
\text { dipping landwards, extending } \\
\text { up to } 20 \mathrm{~m}\end{array}$ & $\begin{array}{l}\text { Well-sorted medium- to } \\
\text { coarse-grained sand } \\
(0.40-0.55 \mathrm{~mm}) \text {. Horizons of } \\
\text { heavy minerals, fragmented shells }\end{array}$ & Transgressive dunes \\
\hline RF3 & $\begin{array}{l}\text { Continuous ( } 50 \mathrm{~m} \text { long), } \\
\text { high-amplitude, subhorizontal } \\
\text { and parallel reflections }\end{array}$ & $\begin{array}{l}\text { Layers of very coarse sediments } \\
\text { from } 0.70 \text { to } 1.10 \mathrm{~mm} \text {. } \\
\text { Fragmented and complete shells }\end{array}$ & Beach backshore \\
\hline RF4 & $\begin{array}{l}\text { High-amplitude reflections } \\
\text { dipping } 5^{\circ}-15^{\circ} \text { seawards }\end{array}$ & - & $\begin{array}{l}\text { Frontal foredune } \\
\text { slope }\end{array}$ \\
\hline RF5 & $\begin{array}{l}\text { High-amplitude complex } \\
\text { sigmoidal reflections dipping } \\
4^{\circ} \text { seawards }\end{array}$ & $\begin{array}{l}\text { Moderately sorted medium- to } \\
\text { coarse-grained sand, shell } \\
\text { fragments }\end{array}$ & Foreshore \\
\hline RF6 & $\begin{array}{l}\text { Low-amplitude } \\
\text { oblique-tangential, landwards } \\
\text { dipping reflectors }\end{array}$ & Medium- to coarse-grained sands & Swash bar \\
\hline
\end{tabular}

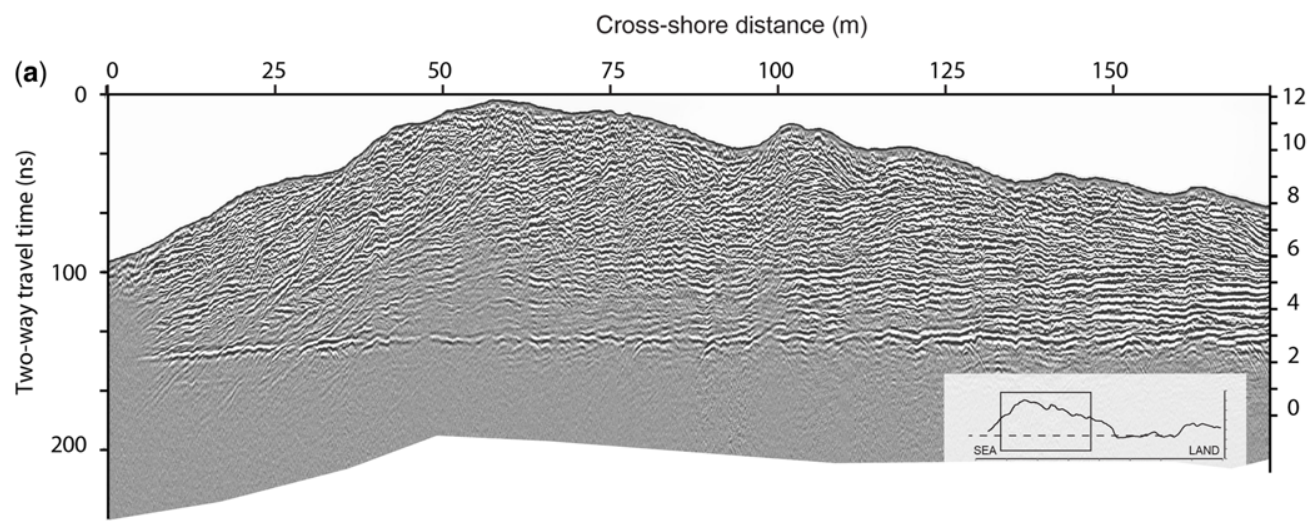

(b)

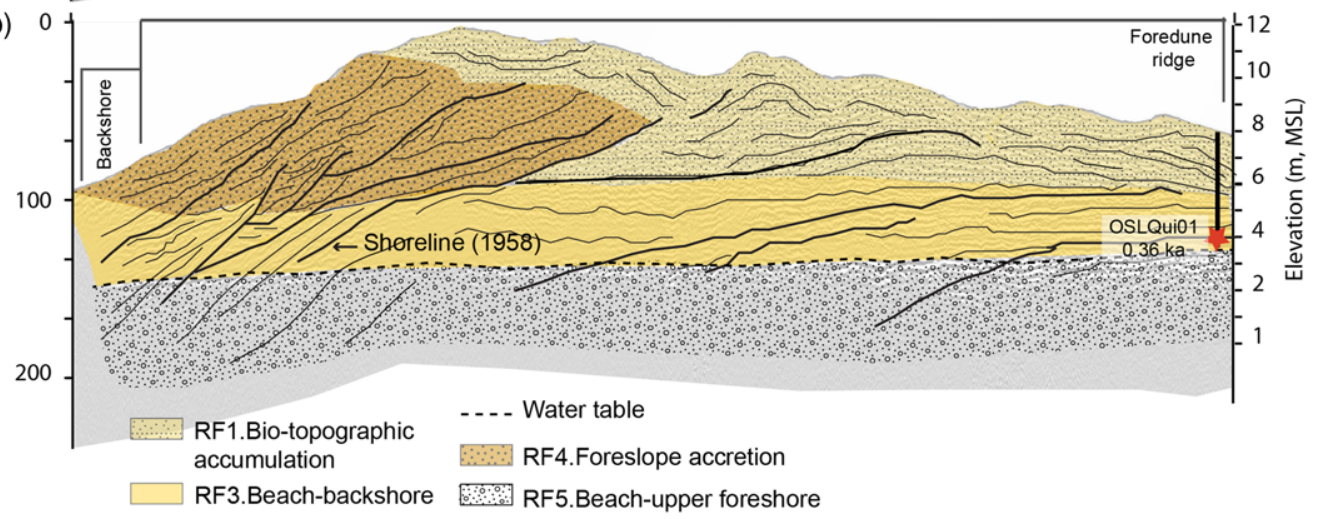

Fig. 5. (a) Seawards segment of the $200 \mathrm{MHz}$ radargram GPR-LQ06. (b) Interpretation of the radargram and the location of the sediment core (vertical line) and OSL sample (asterisks). 


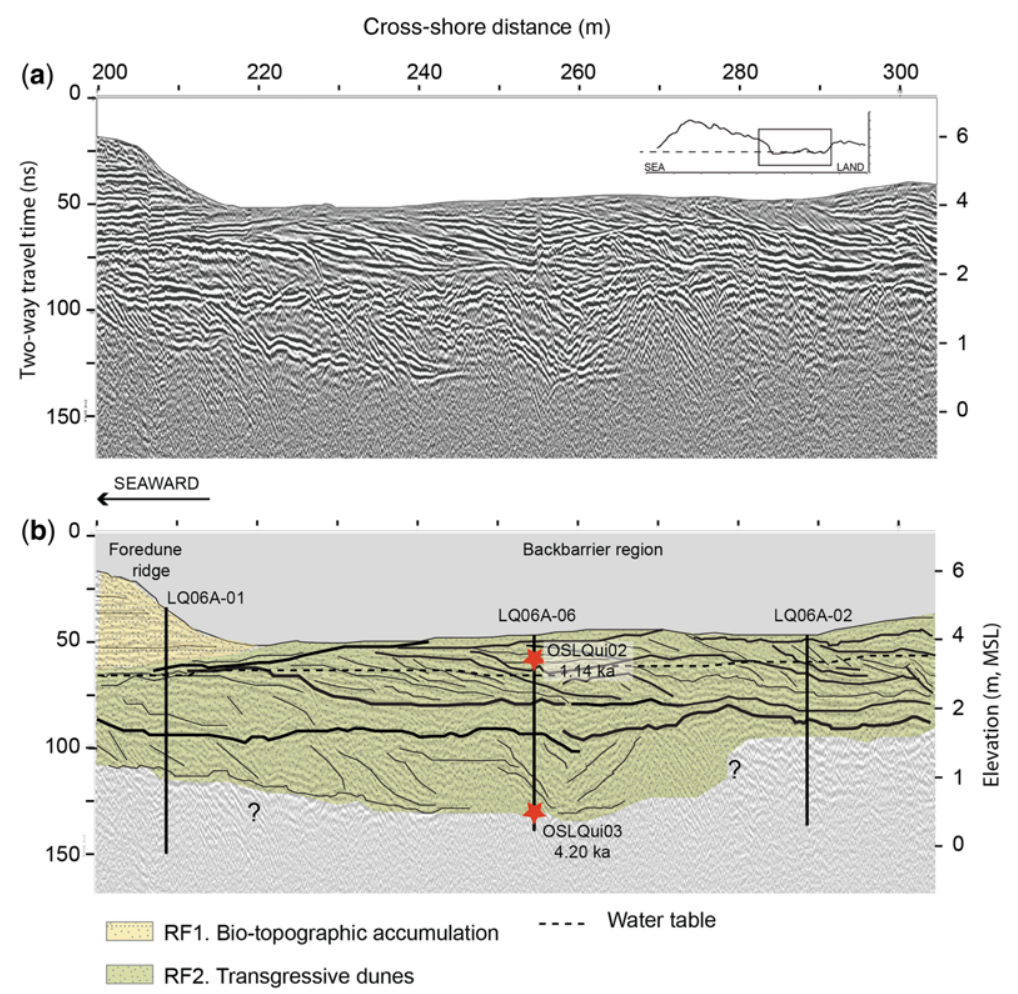

Fig. 6. (a) Segment of the $200 \mathrm{MHz}$ radargram GPR-LQ06 measured across the backbarrier region or depressed area located behind the foredune ridge. (b) Interpretation of the radargram and the location of the sediment cores (vertical lines) and OSL samples (asterisks).

deflation. Sediments within this radar facies range from 0.40 to $0.55 \mathrm{~mm}$ of well-sorted sand and were sampled within the backbarrier region (cores LQ06A-02-LQ06A-05 and LQ09A-03: Fig. 3b, c). Enriched layers of heavy minerals and highly fragmented shells have been observed within the sediment cores, which are dominated by clean, non-organic sediments.

RF3. Beach backshore. Above the water table, continuous, up to $50 \mathrm{~m}$-long reflections represent RF3 (Fig. 5). These facies comprise high-amplitude, subhorizontal and parallel reflections onlapping onto erosive bounding surfaces dipping seawards. RF3 is interpreted as the backshore, which extends from the high tide to the embryo dune. The internal configuration of reflections within RF3 resembles the morphology of the present-day beach, which is approximately $30 \mathrm{~m}$ wide (Fig. 4a). Sedimentation in this area is largely governed by wave swash and the subsequent reworking of the sediment by winds once the mean water level in the region drops and the sand dries (neap tides or lower wave heights). The combined effect of such sand transport and deflation explains the concentration of coarser sediments found in these facies, which range from 0.70 to $1.10 \mathrm{~mm}$ of very coarse quartzose sand. Sediment cores representing these facies were sampled in the backbarrier region north of Tocha Beach (cores LQ09A-01-LQ09A-03: Fig. 3b). Radar packages are frequently truncated by seawards dipping surfaces that suggest the eventual scarping of the upper beach and the retreat of the shoreline.

RF4. Frontal foredune slope. The deposit of the seawards face of the foredune is represented by highamplitude reflections dipping seawards with angles ranging from $5^{\circ}$ to $15^{\circ}$ (RF4: Fig. 5). Internally, radar packages are erosively truncated by steeper and stronger reflectors. Such reflections suggest partial erosion not only of the beach but also of the foredune promoting the development of a cliffed foredune.

RF5. Foreshore. RF5 generally has a poor GPR response except for a few local high-amplitude complex sigmoidal reflections dipping around $4^{\circ}$ seawards (Figs $5 \& 8$ ). Sediments within this radar facies consist of moderately sorted coarse- to 


\section{S. COSTAS ET AL.}
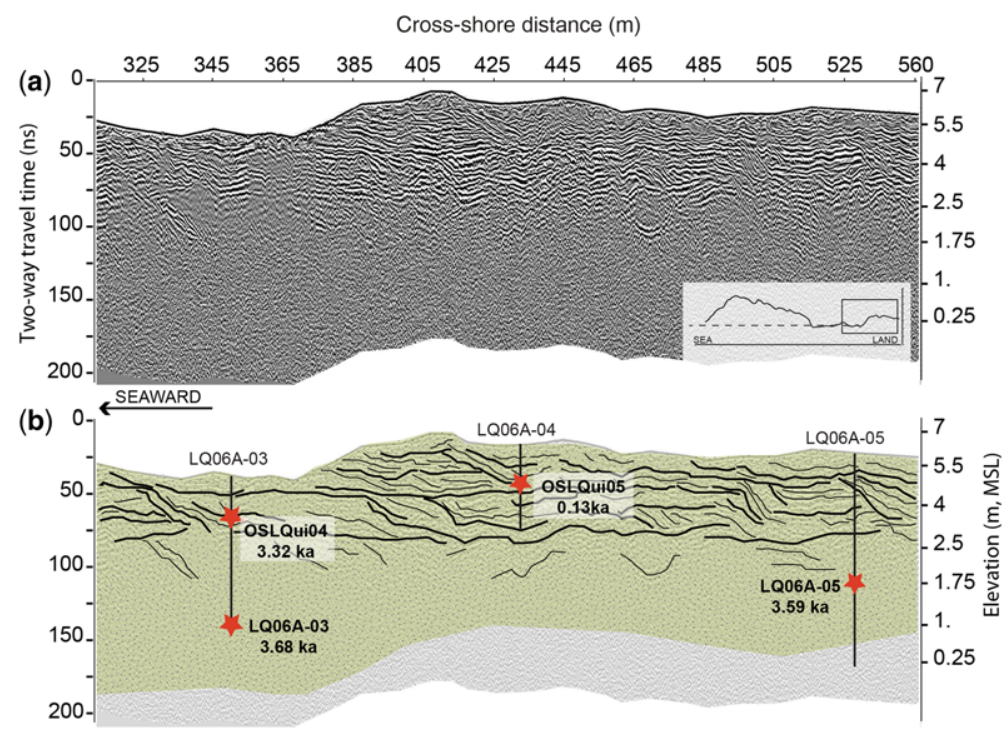

RF2. Transgressive dunes

Fig. 7. (a) Inland segment of the $200 \mathrm{MHz}$ radargram GPR-LQ06 showing the transition towards the transgressive dunefield. (b) Interpretation of the radargram and the location of the sediment cores (vertical lines) and OSL samples (asterisks).

medium-grained sand with a very low content of shell fragments, as seen in Core LQ09A-01 (Fig. 3b). Thi facies is interpreted as representing the seawards progradation of the foreshore.

RF6. Swash bar. RF6 consists of low-amplitude oblique-tangential, landwards dipping reflectors (Fig. 8). RF6 extends from 0 to $2 \mathrm{~m}$ above MSL intercalated within RF5 deposits. Sediment within RF6 was collected from the backbarrier region to the north of Tocha Beach (Core LQ09A-02, Fig. $3 \mathrm{~b})$ and consists of medium- to coarse-grained sands. These sediments were interpreted as having been deposited by landwards migrating and welding of sand bars onto the beach foreshore.

\section{Chronology}

Details of the luminescence age determinations of the dunefield are given in Table 2, and information of their location in depth and within the GPR profiles is presented in Table 3 and Figures 5-8. OSL ages are presented in thousands of years (ka) before 2011 (year of sampling). Sample collection was based on the interpretation of geophysical data, barrier morphology and historical information so that the representative episodes of barrier evolution would be recorded. The OSL ages of the selected radar units range from $4.25 \pm 0.28$ to
$0.13 \pm 0.01 \mathrm{ka}$, indicating that sedimentation of this coastal fringe occurred during the late Holocene. The older set of deposits preserved in the study area extends in time between 4.25 and $3.32 \mathrm{ka}$, and represents the lower units of RF2 (Table 3; Figs 6-9), which were found in the backbarrier region and in the transition towards the major transgressive dunefield. After a depositional hiatus or erosive episode, a new set of aeolian deposits (RF2) was deposited around 1.14-1.04 ka covering the previous one (Table 3; Figs 6,8 \& 9). Conversely, the next episode of sand accumulation preserved in the studied coastal fringe is represented by beach sediments (RF3, RF5 and RF6) prograding seawards since $0.36 \mathrm{ka}$ (Table 3; Figs $5,8 \& 9)$. Finally, the last pulse of aeolian mobilization (RF2 units) in the eastern sector of the study area, in particular in the region of transition between the backbarrier region and the inland transgressive dunefield, was dated at $0.13 \mathrm{ka}$. (Table 3; Figs 7 \& 9).

\section{Subsurface stratigraphy}

The GPR profiles image the internal architecture of the present backshore and foredune ridge, backbarrier region, and the transition towards the inland transgressive dunefield. The distribution of radar facies within the cross-shore profiles is 

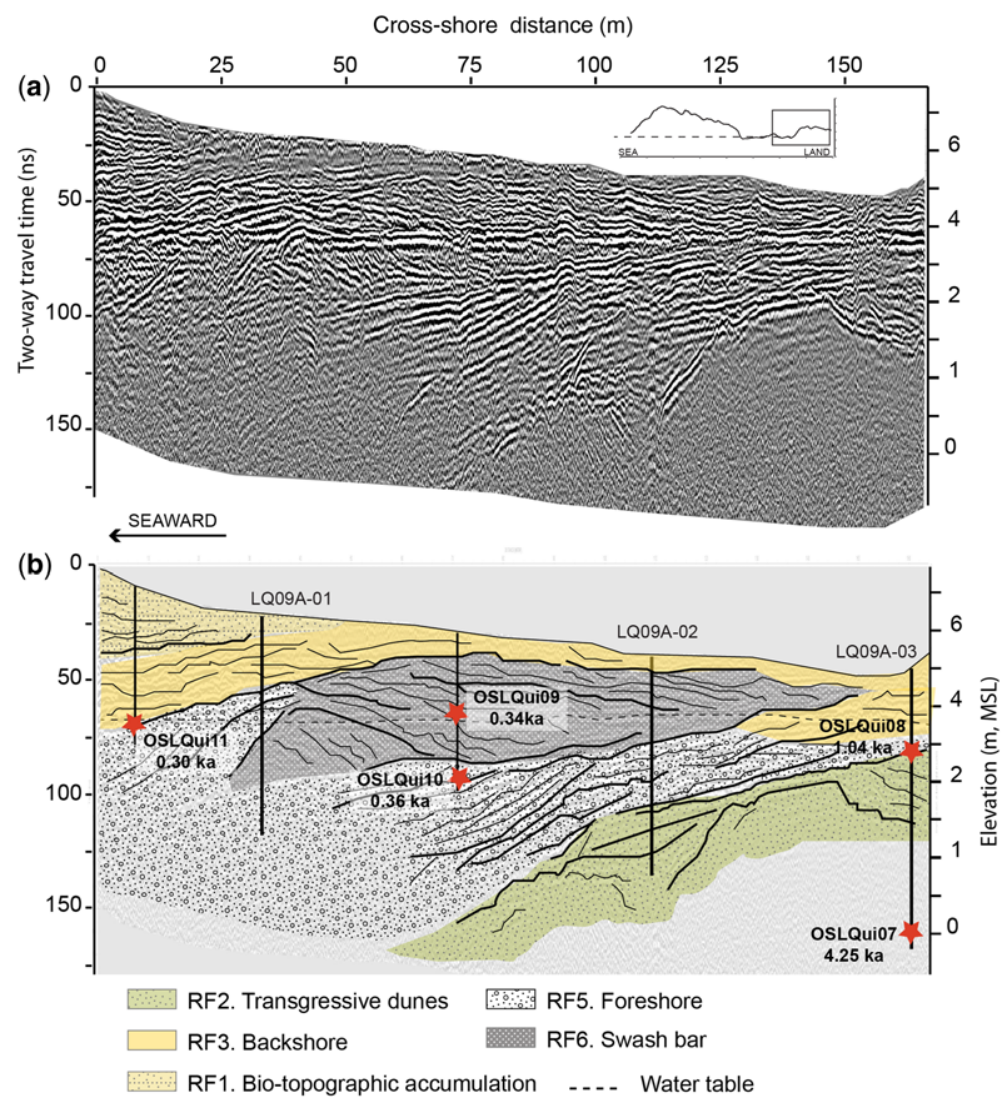

Fig. 8. (a) Segment of the $200 \mathrm{MHz}$ radargram GPR-LQ09 collected in the backbarrier sector. (b) Interpretation of the radargram showing the location of the sediment cores (vertical lines) and OSL samples (asterisks).

markedly different alongshore, allowing the identification of two sectors: northern and southern sectors relative to the location of Tocha Beach (Figs 1b \& 9).

Facies distribution in the southern sector. The distribution of radar facies in the southern sector is best represented by the GPR profile GPR-LQ06 (Figs $1 \mathrm{~b} \& 5-7$ ). Subsurface images of the coastal barrier (present beach and foredune ridge) document three radar facies. Penetration in the foredune ridge was around $6 \mathrm{~m}$, reaching the water table. Despite signal attenuation, high-amplitude reflections cutting through the water table are identified and interpreted as major bounding surfaces. The lower part of the record, below the water table, is interpreted as the sedimentation of RF5 units (Fig. 5). RF5 units underlay units of RF3. The latter appear truncated by seawards dipping bounding surfaces, suggesting episodic erosion of the upper beach. RF3 are replaced seawards by packages of RF4 as the foredune ridge elevation increases, suggesting a change in the style or rate of barrier progradation seawards. The progressive scarping associated with RF4 at the base of the foredune can be related to a relative stabilization of the shoreline. Enhancement of foredune development was associated with the early stages of the negative beach budget, which promotes intermittent scarping of the dune face (Psuty 1992). Conversely, the wide extension of RF3 packages within the landwards part of the dune ridge suggests a period of rapid progradation; successive scarps were separated by approximately $20 \mathrm{~m}$ (Fig. 5). Units of RF1 cover backshore sediments as sediment is accumulated and trapped around vegetation mounds (Fig. 5).

The backbarrier region consists of a topographical depression infilled with RF2 units (Fig. 6). These deposits represent the inland migration of aeolian sands. As aforementioned, the top of the reflectors within RF2 is frequently truncated by deflation surfaces, suggesting the occurrence of successive pulses of sand transference inland. In 
Table 2. Luminescence dating results (OSL ages in years before 2011)

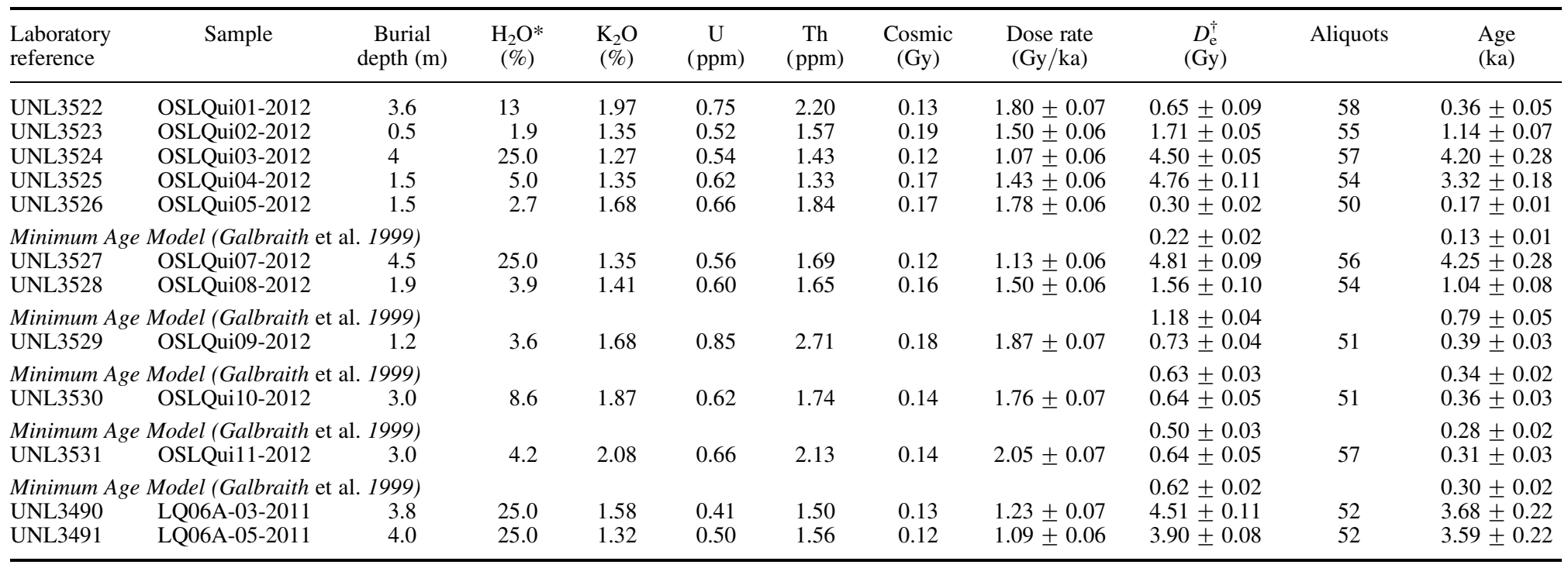

*In-situ moisture content.

${ }^{\dagger}$ Central Age Model (Galbraith et al. 1999) unless otherwise indicated, choice of age model is based upon decision table of Bailey \& Arnold (2006). 
Table 3. Correspondence between the OSL samples, the GPR profiles and distance of the samples relative to the present shoreline

\begin{tabular}{lllcc}
\hline Sample & $\begin{array}{c}\text { GRP } \\
\text { line }\end{array}$ & Facies & $\begin{array}{c}\text { Burial } \\
\text { depth (m) }\end{array}$ & $\begin{array}{c}\text { Cross-shore } \\
\text { distance (m) }\end{array}$ \\
\hline OSLQui01-2012 & GPR-LQ06 & RF3 & 3.6 & 176 \\
OSLQui02-2012 & GPR-LQ06 & RF2 & 0.5 & 242 \\
OSLQui03-2012 & GPR-LQ06 & RF2 & 4 & 242 \\
OSLQui04-2012 & GPR-LQ06 & RF2 & 1.5 & 335 \\
OSLQui05-2012 & GPR-LQ06 & RF2 & 1.5 & 448 \\
OSLQui07-2012 & GPR-LQ09 & RF2 ? & 4.5 & 317 \\
OSLQui08-2012 & GPR-LQ09 & RF2 & 1.9 & 317 \\
OSLQui09-2012 & GPR-LQ09 & RF6 & 1.2 & 232 \\
OSLQui10-2012 & GPR-LQ09 & RF5 & 3.0 & 164 \\
OSLQui11-2012 & GPR-LQ09 & RF5 & 3.0 & 335 \\
LQ06A-03-2011 & GPR-LQ06 & RF2 & 3.8 & 543 \\
LQ06A-05-2011 & GPR-LQ06 & RF2 & 4.0 & \\
\hline
\end{tabular}

addition to the radar facies identified within the collected radargrams, a $15 \mathrm{~cm}$-thick layer was identified on the surface of the backbarrier area as described previously in the subsection on 'Present day coastal system'. Finally, the landwards part of the radargram is characterized by complex internal configurations dominated by subhorizontal and sigmoidal reflections resulting from the vertical accumulation of RF2 radar packages (Fig. 7).

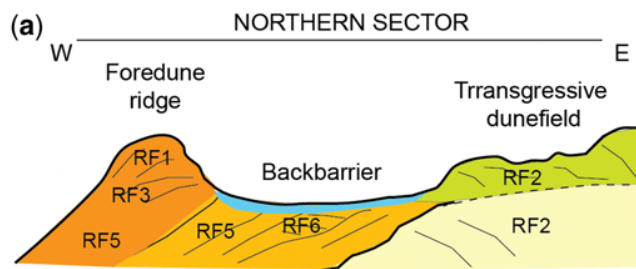

(b)

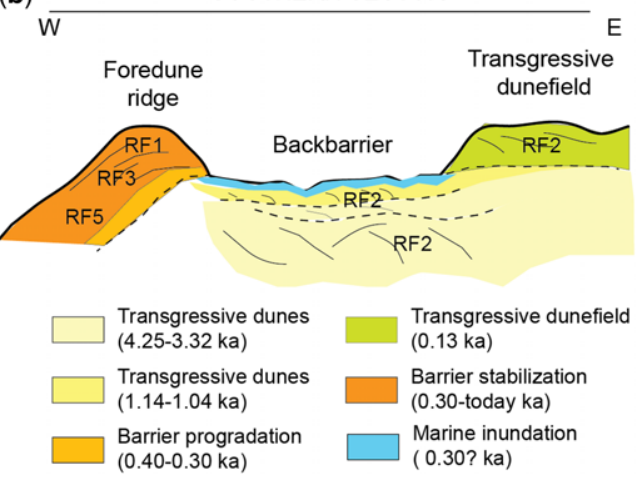

Fig. 9. Diagrams showing the differences between (a) the northern and (b) the southern coastal sectors in terms of facies distribution and ages.
Facies distribution in the northern sector. Facies distribution to the north of Tocha Beach is best represented by the GPR profile GPR-LQ10 (Figs $1 \mathrm{~b} \& 8$ ). The internal architecture of the seawards part of the barrier is characterized by the presence of RF4 clinoforms. Inland, subsurface images of the foredune ridge document three radar facies repeating the architecture observed in the southern sector. The portion above the water table consists of radar facies RF3, which is in turn overlaid by RF1.

The uppermost layers of sediment in the backbarrier region are also characterized by the presence of a $15 \mathrm{~cm}$-thick layer with abundant large and unbroken shells and pebbles. However, the subsurface stratigraphy of this zone is radically different from what was identified in the southern sector. In this case, RF2 units are only identifiable in the landward-most zone of this region, being truncated by a seawards dipping bounding surface overlaid by units of RF5, and suggesting the partial erosion of aeolian deposits and formation of a beach onto the dunes. The internal architecture of most of the backbarrier is dominated by units of RF5, RF6 and RF3 (Fig. 8). Line GPR-LQ09 shows radar packages of RF6 alternating with RF3. The sedimentation in the upper beach of RF6 units suggests sporadic migration and welding of swash bars onto the beachface contributing to berm construction. Preservation of entire swash bars within the architecture of the beach suggests an elevated input of sediment and high progradation rates. This architecture suggests the seawards progradation of a beach anchored to transgressive aeolian deposits.

Longshore variability. The internal stratigraphy of the coastal barrier (present beach and foredune ridge) does not show significant differences 


\section{S. COSTAS ETAL.}

alongshore (Fig. 9). However, significant differences were found in the internal architecture of the backbarrier region alongshore (Fig. 9). The backbarrier depression in the southern sector is dominated by aeolian deposits (south of Tocha Beach: Figs $6 \& 9 b$ ), whereas beach deposits dominate the internal architecture in the northern sector (north of Tocha Beach: Figs 8 \& 9a). Mapping the landwardmost position of the beach sediments aided the delineation of the former shoreline. The latter suggests that the shoreline in the southern sector prograded by about $200 \mathrm{~m}$ seawards, creating the present coastal barrier (present beach and foredune ridge). By contrast, beach progradation in the northern sector extends $400 \mathrm{~m}$ seawards, including the present coastal barrier and the backbarrier region. This suggests that inland penetration during the last marine transgression increased northwards, in the direction of the Aveiro inlet, which reached the northern limit of the studied coastal segment (Mira Beach) in 1756 (Fig. 2).

\section{The recent history of the coastal barrier}

The first evidence of local barrier formation in the study area are the organic-rich sediments interpreted as lagoonal deposits (Danielsen et al. 2012). These sediments were found at the level of present MSL between Quiaios Beach and Tocha Beach, and extend $1 \mathrm{~km}$ inland from the present shoreline, suggesting the formation of a wide lagoon around 4.3 cal ka BP enclosed by a coastal barrier (Danielsen et al. 2012). The authors document the infilling of the lagoon after $3.5 \mathrm{cal} \mathrm{ka}$ BP by aeolian sediments coincident with a shift in the type of vegetation cover from forest to semi-natural heathland between 4 and $1.6 \mathrm{cal} \mathrm{ka}$ BP. The latter attributed to human deforestation (Danielsen et al. 2012). Forest decline was documented in other regions of the Iberian Peninsula after 4 cal ka BP, and was related to drier conditions and to the first evidences of human alterations to the landscapes (Carrión et al. 2007, 2010; Fletcher et al. 2007). In addition, lagoonal sediments were found north of Esmoriz and dated at $4920 \pm 105$ and $4090 \pm 220$ a BP (Granja 1999).

Even though, lagoonal deposits were not found in the subsurface during the present study due to limitations in penetration, we have obtained valuable information on the architecture and age of the aeolian deposits filling the lagoon, and on the development of the present coastal barrier. Our results suggest that aeolian sediments responsible for lagoon infilling were sourced from a proto-barrier and occurred during two episodes, with the first centred between 4.25 and $3.32 \mathrm{ka}$. Episodes of transgressive dune building in coastal systems are frequently triggered by a relative instability in the coastal sediment budget (Psuty 1992). Enhancement of foredune development was associated with the early stages of the negative beach budget, which promotes intermittent scarping of the dune face, and the eventual initiation of blowouts and parabolic dunes (Psuty 1992). Consequently, dune scarping could expose large volumes of sand that become available to be blown by favourable westerly winds. Once transgressive dunes are dissected from the coastal barrier, they migrate inland. The latter could be facilitated by shifts in vegetation cover as noted by Danielsen et al. (2012).

The second episode of dune building and inland sediment transport was centred between 1.14 and $1.04 \mathrm{ka}$, and recorded in the upper units of the aeolian deposits in the backbarrier zone. This episode of aeolian activity may have been be triggered by a new event of shoreline instability provoked by an alteration in the beach budget. This episode is coincident with the development of inland parabolic dunes dated between 1.14 and $0.62 \mathrm{ka}$ to the north of the Aveiro inlet (Granja 2002). The time interval between both aeolian episodes represents a hiatus coincident with the deposit of lagoonal sediments along Furadouro-Torreira around $2 \mathrm{cal}$ ka BP (Bernardes \& Rocha 2007) and at Silvalde at about 2.7 cal ka BP (Granja et al. 1996). In addition, a podzol was formed on the Pleistocene dunes located along Espinho-Ovar between 2.7 and 2 cal ka BP, suggesting reduced aeolian activity (Granja et al. 2008).

Whenever a negative beach sediment budget persists, dramatic changes may affect the coastal barrier triggering barrier overstepping and retrogradation. These conditions could explain the destruction of the proto-barrier along the coastal segment between Mira Beach and Mondego Cape. Once conditions became favourable, a new barrier formed anchored onto the transgressive dunes around 360 years ago. Historical records document the downdrift elongation of a coastal spit starting around 1 ka ago from Espinho (Girão 1941; Abecasis 1954). As the spit elongated southwards and built in front of the estuary, an inlet formed and migrated, reaching its southernmost position in 1756 at Mira Beach (Abecasis 1954). In this position, it became hydraulically inefficient, and navigation through the channel was impeded owing to the accumulation of sand bars. However, this configuration allowed sediments to bypass the inlet to the south of Mira Beach, inducing barrier progradation and restabilizing the sediment budget. In fact, shoaling processes in the inlet were already documented in 1687, indicating efficient sediment bypassing downdrift.

The shoreline stabilized some time after 300 years ago when the barrier progradation trend 
shifted to vertical aggradation, leading to the construction of the present foredune ridge. Prior to this shift, we hypothesize the occurrence of at least one high-energy event responsible for inundating the recently formed coastal barrier and backbarrier region. We believe this event was responsible for depositing the $15 \mathrm{~cm}$ washover layer overlying aeolian and beach deposits. Such an inundation could be related to a very large storm or series of storms inducing high water levels. Indeed, Corrochano et al. (2000) identified two major episodes of washover sedimentation before and after 1756 in the tidal channel north of Mira Beach. The authors related pre-1756 washover deposits to the inundation generated by the 1755 Lisbon tsunami, whereas the deposits generated between 1756 and 1802 were related to a period of enhanced storminess. The later was also suggested by Clarke \& Rendell (2006) to explain aeolian activity in the inland dunefield.

The youngest sediments dated in the present work point to an episode of aeolian activity in the region of transition to the transgressive dunefield 130 years ago (AD 1880). Aeolian activity was also documented within the inland transgressive dunefield between 1770 and 1905 (Clarke \& Rendell 2006), and related to the unstable climate conditions (storminess) affecting the area during the second half of the Little Ice Age. In this case, westerly to northwesterly onshore winds were suggested as the agent for sand mobilization and reactivation of elongated hairpin and complex parabolic forms. Reforestation along the inland transgressive dunefield was artificially completed to stop the inland advance of the dunes in 1926 (Freitas 1940).

\section{Discussion}

The results presented here, together with previous work, suggest the formation of three major features that repeat over time and can be indicative of shoreline trends along the coastal barrier enclosing the Aveiro lagoon: transgressive dunes resulting from major episodes of aeolian activity; lagoonal deposits indicative of ephemeral lagoons enclosed by coastal barriers; and the present coastal barrier.

\section{Dune encroachment and shoreline instability}

Transgressive dunes in the study area were found infilling a lagoon between 4.25 and 3.32, and 1.4 and $1.04 \mathrm{ka}$ ago, and were related to blowout and parabolic dune development resulting from the dissection of former barriers. It is here suggested that these episodes can be triggered by instabilities in the beach budget. The latter may induce dune scarping, exposing large volumes of sand that become available to be blown inland by favourable westerly winds. If so, these events are initiated by coastal processes rather than by changes in vegetation, as previously suggested by Danielsen et al. (2012). In addition, the older ages obtained from the aeolian deposits reported here indicate that the decline in forests documented by Danielsen et al. (2012) was preceded by the first episode of aeolian activity. By contrast, the last episode of aeolian activity dated around 130 years ago was related to a local sediment source derived from the remobilization of the inland dunefield, which could in turn be explained by changes in vegetation cover naturally or artificially induced.

Changes in the beach sediment budget can be related to alterations in the longshore sediment transport induced by changes in sediment input, wave climate and/or sea level. Resolving changes in sediment supply over time may be problematic if sediment sources are not well understood. The Douro River has traditionally been referred to as the major source of sediment to this coastal segment (Oliveira 1997; Taveira-Pinto et al. 2011). However, this has never been actually confirmed in terms of texture and composition (Granja 2000). Nonetheless, the existence of Pleistocene and early Holocene transgressive dunefields involved large volumes of sand, and suggests that even larger volumes could have dominated this coastal segment when sea level was lower. Finally, it is also important to highlight the importance of local sediment sources to explain the presence of quartzite pebbles in the beach. All of these facts question the relative importance of the recent fluvial sediment input and actual consequences of human interventions.

Thus, we consider two sediment sources to the coastal barrier of Aveiro: the first being local (Pleistocene dunes and outcrops); and the second, the fluvial input from the Douro River. The first may have had a significant role during the Holocene transgression, supplying sand to inland transgressive dunes and to former coastal barriers in a similar way to that described by Costas et al. (2012) in the Tagus region, central west coast of Portugal. In addition, Costas et al. (2012) suggested successive episodes of shoreline instability generated by enhanced storminess/relative sea-level changes to explain episodes of aeolian activity resembling those documented here around 4.2 and $1.4 \mathrm{ka}$ ago. Moreover, Costas et al. (2012) related aeolian activity to intense westerly winds, compatible with prolonged negative phases of the NAO. As aeolian activity in the region was driven by onshore winds 


\section{S. COSTAS ET AL.}

(westerly to northwesterly winds) consistent with the windfield regimes documented by Costas et al. (2012), a similar mechanism may have driven aeolian activity in the Aveiro region. This could explain the synchronism between episodes of aeolian activity in the Tagus and Aveiro regions (about $170 \mathrm{~km}$ apart: Fig. 1a) around $1.2 \mathrm{ka}$ ago, and suggest another episode of intense westerly winds and enhanced storminess around $4.2 \mathrm{ka}$ ago.

These events of aeolian activity coincide with significant changes in coastal lagoons along the Iberian Atlantic coast. Lagoons become increasingly brackish as a consequence of more permeable and frequently breached coastal barriers (Cearreta et al. 2003; Freitas et al. 2003; Costas et al. 2009). At the same time, storm deposits were documented in the lagoons and estuaries of the north and south of France (Sabatier et al. 2012; Sorrel et al. 2012). In addition, lake levels and flooding frequency increased in the Iberian Peninsula (Carrión 2002; Thorndycraft \& Benito 2006), supporting the onset of enhanced storminess. Alternatively, episodes of aeolian activity could be related to the onset of submillennial-scale climatic coolings such as the so-called ' $4.2 \mathrm{ka}$ event', a climatic anomaly that may have been global in extent (Marchant \& Hooghiemstra 2004), the cooling event Bond 1 (Bond et al. 2001) and the end of the Little Ice Age (Bradley \& Jonest 1993).

More frequent storms, persistent westerly winds and wetter conditions in the western Mediterranean were related to prolonged negative phases of the North Atlantic Oscillation (Trigo \& DaCamara 2000). The onset of stormy conditions could also induce a counterclockwise shift in wave climate, reducing longshore sediment transport. Since barrier construction in the study area is a consequence of spit elongation, a reduction of the longshore sediment transport, in addition to frequent storms, could alter beach sediment budget, and induce foredune destruction and transgressive dune building with subsequent landwards sediment transport by onshore (Davidson-Arnott et al. 2005) or oblique winds (Bauer \& Davidson-Arnott 2003). Therefore, we interpret episodes of aeolian activity as indicators of shoreline instability and barrier retrogradation induced by changes in longshore sediment transport.

It has been suggested that changes in sea level may also contribute to sediment budget instability in the coastal system. However, considering that the sea-level rise rate stabilized and significantly reduced around $7 \mathrm{ka}$ ago (Vis et al. 2008; Leorri et al. 2013), we do not consider this factor as a trigger mechanism during these short-term events, although it must contribute to the overall retrograding trend of the system. Finally, it is assumed that neotectonics had a minimal impact on the evolution of the coast (Vis et al. 2008; Leorri et al. 2013).

\section{Episodes of shoreline progradation and stability}

Barrier formation over time was inferred from the occurrence of lagoonal sediments (Rocha \& Bernardes 1997; Granja 1999; Bernardes \& Rocha 2007; Danielsen et al. 2012), historical records (Girão 1941; Abecasis 1954) and from barrier sediments (present work). Our results and compiled information indicate that lagoon formation and aeolian activity occurred during different time episodes, suggesting contrasting beach sediment budgets.

Episodes of barrier growth or spit elongation suggest periods of abundant sediment availability, including the reworking of underlying Pleistocene deposits or efficient longshore sediment transport. Periods of barrier growth inferred from lagoonal sediments were documented at $4920 \pm 105$ a BP in the vicinity of Espinho (Granja 1999), 4.3 cal ka BP between Mondego Cape and Tocha Beach (Danielsen et al. 2012), around 2 cal ka BP along Furadouro-Torreira (Bernardes \& Rocha 2007) and 2.7 cal ka BP at Silvalde (Granja et al. 1996) (Fig. 1). In addition, a podzol was deposited on the Pleistocene dunes located along Espinho-Ovar between 2.7 and 2 cal ka BP, suggesting reduced aeolian activity (Fig. 1) (Granja et al. 2008). These results suggest the onset of several lagoonal environments over time, although it is not clear whether there was a single barrier extending alongshore the entire bay or several barriers enclosed the documented lagoons.

The first evidence of barrier formation is coincident with the onset of many coastal barriers and deltas all over the world due to the mid-Holocene sea-level stabilization (Stanley \& Warne 1994; Bao et al. 2007; Bird et al. 2007). Sediment sources for barrier growth during this epoch were probably littoral deposits formed by the reworking of underlying Pleistocene sediments during marine transgression. Evidence for the onset of a lagoon during this epoch was found in the littoral segment between Quiaios Beach and Tocha Beach by Danielsen et al. (2012), and in the vicinity of Espinho by Granja (Granja 1999). The latter was only found in one core, suggesting lower preservation of this layer north of Aveiro.

The second episode of lagoonal sedimentation could be related to the coastal barrier previously formed or to the formation of a new barrier following barrier retrogradation. In this case, barrier growth could have been stimulated by efficient longshore sediment transport, and increased 
sediment input from the rivers or reworked Pleistocene and Holocene local sands. It has been suggested that fluvial sediment input could be favoured as deforestation and agriculture in the watersheds advanced (Hoffmann 1990; Dinis et al. 2006). However, it is not clear that the incidence of such activities affected sediment transference to coastal systems. The analysis of the late Holocene fluvial record in the floodplain of the Tagus River indicates minor changes in sediment grain size and sedimentation rate during the Roman Period (Vis et al. 2010b). In addition, it has been observed that changes in land occupation are coincident with an increase of silty sediments delivered to the estuaries due to the erosion of soils (Vis et al. 2010b). However, this episode of shoreline stability is coincident with the onset of the Roman Warm Period (Bianchi \& McCave 1999; McDermott et al. 2001; Büntgen et al. 2011), which is characterized in the Iberian Peninsula by an increase in temperatures (Martínez-Cortizas et al. 1999; Desprat et al. 2003) and enhanced marine upwelling driven by intense northerly winds from spring to autumn (Lebreiro et al. 2006). Intense northerly winds in the area prompt longshore sediment transport, contributing to the maintenance of the beach sediment budget.

Historical maps document southwards elongation of a spit $1 \mathrm{ka}$ ago (Girão 1941; Abecasis 1954). This trend, together with the growth of several coastal barriers (Dias et al. 2000) and the progradational infill of rivers and lagoons (Hoffmann 1990; Dinis et al. 2006), was associated with an increase of continental sediment supply due to human impact on upstream watersheds. However, as discussed here, this spit represents the last episode of barrier growth in the area and could hardly be related to an increase in sediment supply by rivers as they are contributing to the progradation of stream mouths (Dinis et al. 2006) by mostly introducing silt (Vis et al. 2008). The late episode of barrier growth could derive from a positive sediment budget in the coastal system promoted by increased longshore sediment transport. This condition may be related to the Medieval Climate Anomaly, which has been suggested as a period of persistent positive mode of NAO circulation (Trouet et al. 2009) associated with more frequent northerly winds in the Iberian Peninsula (Trigo et al. 2008).

Finally, the elongation of the spit downdrift reached Mira Beach only 360 years ago, allowing the seawards progradation of the barrier from Mira Beach to Quiaios Beach, as reported in the present work. The last episode of spit elongation is coincident with a period of enhanced storminess at the onset of the Little Ice Age (Costas et al. 2012), which apparently contributed to the shoaling of the Aveiro inlet (Abecasis 1954). The large volume of sediment moved onshore contributed to the progradation of the coastal segment due to the large volumes of sediment available in the shoaling inlet.

\section{Conclusions}

The analysis of the stratigraphy of the present-day coastal barrier and backbarrier region provides a means of reconstructing the evolution of the coastal segment between Mira Beach and Quiaios Beach in the northern coast of Portugal. In this regard, the combination of geophysical (GPR), dating (OSL) and sedimentological analysis of the present-day coastal section allowed the identification of the maximum marine transgression, the progradation of the present coastal barrier and the sedimentation of transgressive dunes during two separated events. The presence of foreshore deposits prograding seawards documents the onset of the present-day barrier between Mira Beach and Quiaios Beach only 400 years ago. Alternatively, two major pulses of aeolian activity interpreted as the dismantling of coastal barriers through the inland transport of aeolian sand 4.25-3.32 and $1.14-1.04 \mathrm{ka}$ ago suggests the existence of older coastal barriers. These events were related to negative beach sediment budgets induced by changes in the longshore sediment transport that could ultimately derive from enhanced storminess and wave rotation. However, compiled information from previous work undertaken in the region document the presence of lagoonal deposits either buried by aeolian deposits or outcropping in the present foreshore. These deposits suggest the existence of large lagoons enclosed by ephemeral coastal barriers before and after every episode of dune building, confirming the existence of older barriers that were later dismantled. The above suggests that the central coast of Portugal has undergone several episodes of barrier retrogradation during the midlate Holocene, alternating with periods of shoreline stability and barrier growth as a consequence of changes in longshore sediment transport. The latter has been related to shifts on the major mode of atmospheric circulation in the North Atlantic, the North Atlantic Oscillation (NAO). Persistent negative values of NAO are associated with enhanced storminess and westerly winds that in turn may contribute to negative beach sediment budget under normal circumstances. The opposite was suggested during periods of persistent positive values of NAO, which appear to contribute to the longshore sediment transport and, thus, to barrier growth.

This research was founded by the Portuguese Science Foundation (FCT) through the projects SCARPS (PTDC/CTE-GIX/101466/2008). S. Costas thanks the 


\section{S. COSTAS ETAL.}

FCT for financial support through the program Ciência2007. We would like to thank G. Menezes, M. Ferraz and R. González for their help with fieldwork. Special thanks are given to the editor, I. P. Martini, for his support and useful reviews on the first draft version.

\section{References}

Abecasis, C. 1954. The history of a tidal lagoon inlet and its imporvement (the case of Aveiro, Portugal). In: Johnson, J. W. (ed.) 5th Conference on Coastal Engineering. Council on Wave Research, Grenoble, 329-368.

Adamiec, G. \& Aitken, M. 1998. Dose-rate conversion factors: update. Ancient TL, 16, 37-50.

Aitken, M. J. 1998. An Introduction to Optical Dating. The Dating of Quaternary Sediments by the Use of Photon-stimulated Luminescence. Oxford University Press, New York.

AlmeidA, A. C. 2012. As dunas litorais entre Quiaios e Aveiro. Revista de Geografia e Ordenamento do Território, 2, 7-23.

Andrade, C., Freitas, C., Cachado, C., Cardoso, A. C., Monteiro, J. H., Brito, P. \& Rebelo, L. 2002. Coastal Zones. In: SAntos, F. D., Forbes, K. \& Morta, R. (eds) Climate Change in Portugal. Scenarios, Impacts and Adaptation Measures (SIAM Project). SIAM I, Gradiva, Lisboa, 173-219.

BAILEy, R. M. \& ARNOLD, L. J. 2006. Statistical modeling of single grain quartz $\mathrm{D}_{\mathrm{e}}$ distributions and an assessment of procedures for estimating burial dose. Quaternary Science Reviews, 25, 2475-2502.

Bao, R., Freitas, M. C. \& Andrade, C. 1999. Separating eustatic from local environmental effects: a lateHolocene record of coastal change in Albufeira Lagoon, Portugal. The Holocene, 9, 341-352.

Bao, R., Alonso, A., Delgado, C. \& Pages, J. L. 2007. Identification of the main driving mechanisms in the evolution of a small coastal wetland (Traba, Galicia, NW Spain) since its origin 5700 cal yr BP. Palaeogeography, Palaeoclimatolology, Palaeoecology, 247, 296-312.

Barata, A., Teles, M. \& Vieira, J. R. 1996. Selecção de Ondas Representativas da Agitação Marítima para efeito da Avaliação do Transporte Litoral na Costa de Aveiro. Recursos Hídricos, 17, 43-74.

Bauer, B. O. \& Davidson-Arnott, R. G. D. 2003. A general framework for modeling sediment supply to coastal dunes including wind angle, beach geometry, and fetch effects. Geomorphology, 49, 89-108.

BEAUMONT, L. É. D. 1845. Leçons de géologie pratique. 7 me Leçon - Levées de Sables et Galets. P. Bertrand, Paris, 221-252.

Bernardes, C. \& Rocha, F. 2007. Temporal evolution of the sand-spit between Torreira and Furadouro (NW Portugal). Journal of Coastal Research, Special Issue 50, 1092-1096.

Bianchi, G. G. \& McCave, I. N. 1999. Holocene periodicity in North Atlantic climate and deep-ocean flow south of Iceland. Nature, 397, 515-517.

Bird, M. I., Fifield, L. K., Teh, T. S., Chang, C. H., Shirlaw, N. \& Lambeck, K. 2007. An inflection in the rate of early mid-Holocene eustatic sea-level rise: a new sea-level curve from Singapore. Estuarine, Coastal and Shelf Science, 71, 523-536.

Bond, G., Kromer, B. et aL. 2001. Persistent solar influence on North Atlantic climate during the Holocene. Science, 294, 2130-2136.

Bradley, R. S. \& Jonest, P. D. 1993. 'Little Ice Age' summer temperature variations: their nature and relevance to recent global warming trends. The Holocene, 3, 367-376.

Brennan, B. J. 2003. Beta doses to spherical grains. Radiation Measurements, 37, 299-303.

Bristow, C. S. \& Pucillo, K. 2006. Quantifying rates of coastal progradation from sediment volume using GPR and OSL: the Holocene fill of Guichen Bay, south-east South Australia. Sedimentology, 53, 769-788.

Bristow, C. S., Chroston, P. N. \& Bailey, S. D. 2000. The structure and development of foredunes on a locally prograding coast: insights from groundpenetrating radar surveys, Norfolk, UK. Sedimentology, 47, 923-944.

Brooks, G. R., Doyle, L. J., Davis, R. A., DeWitt, N. T. \& Suthard, B. C. 2003. Patterns and controls of surface sediment distribution: west-central Florida inner shelf. Marine Geology, 200, 307-324.

Büntgen, U., Tegel, W. ET AL. 2011. 2500 years of European climate variability and human susceptibility. Science, 331, 578-582.

Buynevich, I. V., FitzGerald, D. M. \& Goble, R. J. 2007. A $1500 \mathrm{yr}$ record of North Atlantic storm activity based on optically dated relict beach scarps. Geology, 35, 543-546.

Cabral, M. C., Freitas, M. C., Andrade, C. \& Cruces, A. 2006. Coastal evolution and Holocene ostracods in Melides lagoon (SW Portugal). Marine Micropaleontology, 60, 181-204.

Carrión, J. S. 2002. Patterns and processes of Late Quaternary environmental change in a montane region of southwestern Europe. Quaternary Science Reviews, 21, 2047-2066.

Carrión, J. S., Fuentes, N., González-Sampériz, P., Sánchez Quirante, L., Finlayson, J. C., FernánDEZ, S. \& ANDRADE, A. 2007. Holocene environmental change in a montane region of southern Europe with a long history of human settlement. Quaternary Science Reviews, 26, 1455-1475.

Carrión, J. S., Fernández, S. et aL. 2010. Expected trends and surprises in the Lateglacial and Holocene vegetation history of the Iberian Peninsula and Balearic Islands. Review of Palaeobotany and Palynology, 162, 458-475.

Carvalho, M. \& Capitão, R. 1996. Valores extremos da agitação marítima na costa Oeste de Portugal. Recursos Hídricos, 17, 33-42.

Cearreta, A., Cachão, M., Cabral, M. C., Bao, R. \& Ramalho, M. J. 2003. Lateglacial and Holocene environmental changes in Portuguese coastal lagoons 2: microfossil multiproxy reconstruction of the Santo André coastal area. The Holocene, 13, 447-458.

Clarke, M. L. \& Rendell, H. M. 2006. Effects of storminess, sand supply and the North Atlantic Oscillation on sand invasion and coastal dune accretion in western Portugal. The Holocene, 16, 341-355. 
Corrochano, A., García-Merino, S., Barba, P. \& BerNARDES, C. A. 2000. Los sedimentos del canal mareal de Mira (Aveiro, Portugal)propiedades texturales, procedencia y modelo paleográfico. Studia geologica salmanticensia, 36, 143-160.

Costa, C. L. 1994. Wind Wave Climatology of the Portuguese Coast. LNEC Report 6/94-A. Instituto Hidrografico, Lisboa.

Costas, S., Muñoz-Sobrino, C., Alejo, I. \& PérezArlucEA, M. 2009. Holocene evolution of a rockbounded barrier-lagoon system, Cíes Islands, northwest Iberia. Earth Surface Processes and Landforms, 34, 1575-1586.

Costas, S., Jerez, S., Trigo, R. M., Goble, R. \& Rebêlo, L. 2012. Sand invasion along the Portuguese coast forced by westerly shifts during cold climate events. Quaternary Science Reviews, 42, 15-28.

Cowell, P. J., Roy, P. S. \& Jones, R. A. 1995. Simulation of large-scale coastal change using a morphological behaviour model. Marine Geology, 126, 45-61.

Daniels, D. J. 2005. Ground Penetrating Radar. Encyclopedia of $R F$ and Microwave Engineering. Wiley, Edison, NJ.

Danielsen, R., Castilho, A. M., Dinis, P. A., Almeida, A. C. \& Callapez, P. M. 2012. Holocene interplay between a dune field and coastal lakes in the Quiaios - Tocha region, central littoral Portugal. The Holocene, 22, 383-395.

Davidson-Arnott, R. G. D., MacQuarrie, K. \& AagaARD, T. 2005. The effect of wind gusts, moisture content and fetch length on sand transport on a beach. Geomorphology, 68, 115-129.

Desprat, S., Sánchez GoÑi, M. A. F. \& Loutre, M.-F. 2003. Revealing climatic variability of the last three millennia in northwestern Iberia using pollen influx data. Earth and Planetary Science Letters, 213, 63-78.

Dias, J., Boski, T., Rodrigues, A. \& Magalhães, F. 2000. Coast line evolution in Portugal since the Last Glacial Maximum until present -a synthesis. Marine Geology, 170, 177-186.

Dinis, J. L., Henriques, V., Freitas, M. C., Andrade, C. \& Costa, P. 2006. Natural to anthropogenic forcing in the Holocene evolution of three coastal lagoons (Caldas da Rainha valley, western Portugal). Quaternary International, 150, 41-51.

Durcan, J. A. \& Duller, G. A. T. 2011. The fast ratio: a rapid measure for testing the dominance of the fast component in the initial OSL signal from quartz. Radiation Measurements, 46, 1065-1072.

EUROSION 2003. EUROSION. Pilot site of River DouroMondego Cape. Report of Project Eurosion I. European Initiative for Sustainable Coastal Erosion Management (EUROSION), The Hague.

Evans, M. W., Hine, A. C., Belknap, D. F. \& Davis, R. A. JR. 1985. Bedrock controls on barrier island development: West-central Florida coast. Marine Geology, 63, 263-283.

Ferreira, O. 1998. Morfodinâmica de praias expostas : Aplicação ao sector costeiro Aveiro - Cabo Mondego. $\mathrm{PhD}$ thesis, Universidade do Algarve, Faro, Portugal.

FitzGerald, D. M., Fenster, M. S., Argow, B. A. \& Buynevich, I. V. 2008. Coastal impacts due to sea-level rise. Annual Review of Earth and Planetary Sciences, 36, 601-647.

Fletcher, W. J., Boski, T. \& Moura, D. 2007. Palynological evidence for environmental and climatic change in the lower Guadiana valley, Portugal, during the last 13000 years. The Holocene, 17, 481-494.

Freitas, A. S. B. 1940. Dunas de Quiaios. Breves notas sobre a sua arborização. Figueira da Foz, Portugal.

Freitas, M. C., Andrade, C. et AL. 2003. Lateglacial and Holocene environmental changes in Portuguese coastal lagoons 1: the sedimentological and geochemical records of the Santo André coastal area. The Holocene, 13, 433-446.

Galbraith, R. F., Roberts, R. G., Laslett, G. M., YoshidA, H. \& Olley, J. M. 1999. Optical dating of single and multiple grains of quartz from Jinmium Rock Shelter, Northern Australia: Part I, experimental design and statistical models. Archaeometry, 41, $339-364$.

GILBERT, G. K. 1890. Lake Bonneville: U.S. United States Geological Survey, Monographs, 1.

GIRÃo, A. d. A. 1941. Geografia de Portugal. Portucalensa editora, Porto, Portugal.

Granja, H. M. 1996. A laguna de Aveiro no contexto da evolução da zona costeira do noroeste de Portugal. In: EUROCOAST-PoRTUGAL (ed.) Lagunas Costeiras e Ilhas-Barreira da Zona Costeira de Portuga. Associação EUROCOAST-Portugal, Aveiro, 87-106.

Granja, H. M. 1999. Evidence for Late Pleistocene and Holocene sea-level, neotectonic and climate control in the coastal zone of northwest Portugal. Geologie en Mijnbouw, 77, 233-245.

Granja, H. M. 2000. A geologia do Holocénico aplicada ao ordenamento da zona costeira. Estudos do Quaternário, 3, 73-90.

GranJa, H. M. 2002. Reconstituição paleoambiental da zona costeira, a norte da Laguna de Aveiro, desde a Idade Media até à actualidade. In: Amorim, I., Polonia, A. \& Osswald, H. (eds) O Litoral em perspectiva histórica (Séc. XVI a XVIII). Instituto de História Moderna, Porto, Portugal, 93-109.

Granja, H. M. \& De Groot, T. A. M. 1996. Sea-level rise and neotectonism in a Holocene coastal environment as Cortegaça Beach (NW Portugal): a case study. Journal of Coastal Research, 12, 160-170.

Granja, H. M., Carvalho, G., De Groot, T., Soares, M. \& PARISH, R. 1996. Geochronology and the recent geomorphological evolution of the northwest coastal zone of Portugal. In: TAussK, J. \& Mitchell, J. (eds) Partnership in Coastal Zone Management. Samara Publishing, Hereford, 297-308.

Granja, H. M., Groot, T. A. M. D. \& Costa, A. L. 2008 Evidence for Pleistocene wet aeolian dune and interdune accumulation, S. Pedro da Maceda, north-west Portugal. Sedimentology, 55, 1203-1226.

Granja, H. M., Rocha, F., Matias, M., Moura, R., Caldas, F., Marques, J. \& Tareco, H. 2010. Lagoa da Apúlia: a residual lagoon from the Late Holocene (NW coastal zone of Portugal). Quaternary International, 221, 46-57.

Guerin, G., Mercier, N. \& Adamiec, G. 2011. Dose-rate conversion factors: update. Ancient TL, 29, 5-8.

HoffmanN, G. 1990. Estratigrafia holocenica e evolocao da linha da costa nos vales dos rios Sizandro (Portugal) 


\section{S. COSTAS ETAL.}

e Guadiana (Portugal e Espanha). In: Ambientes Geológicos Litorais: Actas; VI Simpósio de Geologia Aplicada e do Ambiente, Lisboa. Departamento de Geologia da F. C. U. L., Lisboa, 115-128.

Ноут, J. H. 1967. Barrier Island formation. Geological Society of America Bulletin, 78, 1125-1136.

Lebreiro, S. M., Francés, G. et al. 2006. Climate change and coastal hydrographic response along the Atlantic Iberian margin (Tagus Prodelta and Muros Ría) during the last two millennia. The Holocene, 16, 1003-1015.

Leorri, E., Fatela, F., Drago, T., Bradley, S. L., Moreno, J. \& Cearreta, A. 2013. Lateglacial and Holocene coastal evolution in the Minho estuary ( $\mathrm{N}$ Portugal): implications for understanding sea-level changes in Atlantic Iberia. The Holocene, 23, 353-363.

Marchant, R. \& Hooghiemstra, H. 2004. Rapid environmental change in African and South American tropics around 4000 years before present: a review. Earth-Science Reviews, 66, 217-260.

Martínez-Cortizas, A., Pontevedra-Pombal, X., García-Rodeja, E., Nóvoa-Muñoz, J. C. \& Shotyk, W. 1999. Mercury in a Spanish Peat Bog: archive of climate change and atmospheric metal deposition. Science, 284, 939-942.

Masetti, R., Fagherazzi, S. \& Montanari, A. 2008. Application of a barrier island translation model to the millennial-scale evolution of Sand Key, Florida. Continental Shelf Research, 28, 1116-1126.

McDermott, F., Mattey, D. P. \& Hawkesworth, C. 2001. Centennial-scale Holocene climate variability revealed by a high-resolution speleothem $\delta 18 \mathrm{O}$ record from SW Ireland. Science, 294, 1328-1331.

Méndez, G., Pérez-Arlucea, M., Stouthammer, E. \& BerensDen, H. 2003. The TESS-1 suction corer: a new device to extract wet, uncompacted sediments. Journal of Sedimentary Research, 73, 1078-1081.

Menezes, G. 2011. Estudo da evolução da linha de costa entre o cabo Mondego e Aveiro (1958-2010). PhD thesis, Universidade de Coimbra, Coimbra, Portugal.

Mitchum, J. R. M., Vail, P. R. \& Sangree, J. B. 1977. Seismic stratigraphy and global changes of sea level - Part 6: stratigraphic interpretation of seismic reflection patterns in depositional sequences. In: PAYTON, C. E. (ed.) Seismic Stratigraphy - Applications to Hydrocarbon Exploration. American Association of Petroleum Geologists, Memoirs, 26, 117-133.

Murray, A. S. \& Wintle, A. G. 2000. Luminescence dating of quartz using an improved single-aliquot regenerative-dose protocol. Radiation Measurements, 32, 57-73.

Murray, A. S. \& Wintle, A. G. 2003. The single aliquot regenerative dose protocol: potential for improvements in reliability. Radiation Measurements, 37, $377-381$.

Naughton, F., Sanchez Goni, M. F., Drago, T., Freitas, M. C. \& Oliveira, A. 2007. Holocene changes in the Douro Estuary (Northwestern Iberia). Journal of Coastal Research, 23, 711-720.

NoIvo, L. M. S. 1996. Morfologia e Dinâmica Sedimentar das Dunas de Quiaios, Portugal. PhD thesis, Universidade de Aveiro, Aveiro, Portugal.

Oliveira, I. B. M. 1997. Proteger ou não proteger ou sobre a viabilidade de diferentes opções face à erosão da costa oeste Portuguesa. In: EUROCOAST-PorTUGAL (ed.) Colectânea de Ideias sobre a Zona Costeira de Portugal. Associação EUROCOAST-Portugal, Porto, 205-228.

Oliveira, I. B. M., Valle, A. J. S. F. \& Miranda, F. C. C. 1982. Littoral problems in the Portuguese West Coast. In: EdGE, B. L. (ed.) Coastal Engineering. 18th International Conference on Coastal Engineering; November 14-19, 1982, Cape Town, South Africa. American Society of Civil Engineers (ASCE), Reston, VA, 1950-1969.

Prescott, J. R. \& Hutton, J. T. 1994. Cosmic ray contributions to dose rates for luminescence and ESR dating: large depths and long-term time variations. Radiation Measurements, 23, 497-500.

Psuty, N. P. 1992. Spatial variation in coastal foredune development. In: Carter, R. W. G., Curtis, T. G. F. \& Sheehy-Skeffington, M. J. (eds) Coastal Dunes: Geomorphology, Ecology, and Management for Conservation. Balkema, Rotterdam, 3-13.

RAMPINO, M. R. \& SANDERS, J. E. 1981. Evolution of the barrier islands of southern Long Island, New York. Sedimentology, 28, 37-47.

Rocha, F. \& Bernardes, C. 1997. Caracterização mineralógica dos níveis lodosos no sistema de dunas costeiras a sul do Cabo Mondego. Quaternary Studies, 1, $67-72$.

RoDNight, H. 2008. How many equivalent dose values are needed to obtain a reproducible distribution? Ancient $T L$, 26, 3-9.

Sabatier, P., Dezileau, L. ET AL. 2012. 7000 years of paleostorm activity in the NW Mediterranean Sea in response to Holocene climate events. Quaternary Research, 77, 1-11.

SERVIÇO METEOROLÓGICO NACIONAL 1974. Atlas climatológico de Portugal continental. Instituto Geográfico Português, Lisboa.

Sorrel, P., Debret, M., Billeaud, I., Jaccard, S. L., McManus, J. F. \& Tessier, B. 2012. Persistent nonsolar forcing of Holocene storm dynamics in coastal sedimentary archives. Nature Geoscience, 5, 892-896.

Stanley, D. J. \& Warne, A. G. 1994. Worldwide initiation of Holocene marine deltas by deceleration of sea-level rise. Science, 265, 228-231.

Stolper, D., List, J. H. \& Thieler, E. R. 2005. Simulating the evolution of coastal morphology and stratigraphy with a new morphological-behaviour model (GEOMBEST). Marine Geology, 218, 17-36.

Taveira-Pinto, F., Silva, R. \& Pais-Barbosa, J. 2011. Coastal erosion along the Portuguese Northwest Coast due to changing sediment discharges from rivers and climate change. In: ScHERNEWSKI, G., HoFstede, J. \& Neumann, T. (eds) Global Change and Baltic Coastal Zones, Volume 1. Springer, Dordrecht, $135-151$.

Teixeira, S. B., Gaspar, P. \& Rosa, M. 2005. Evolução holocénica do litoral em regime transgressivo: o caso da costa de Quarteira (Aklgarve, Portugal). In: Freitas, M. d. C. \& Drago, T. (eds) Iberian Coastal Holocene Paleoenvironmental Evolution - Coastal Hope 2005 - Proceedings. Universidade de Lisboa, Lisboa, 121-124.

Thorndycraft, V. R. \& Benito, G. 2006. The Holocene fluvial chronology of Spain: evidence from a newly 


\section{BARRIER GROWTH, CENTRAL COAST OF PORTUGAL}

compiled radiocarbon database. Quaternary Science Reviews, 25, 223-234.

Trigo, R. M. \& DaCamara, C. C. 2000. Circulation weather types and their influence on the precipitation regime in Portugal. International Journal of Climatology, 20, 1559-1581.

Trigo, R. M., Valente, M. A., Trigo, I. F., Miranda, P. M. A., Ramos, A. M., Paredes, D. \& GarcíaHerrera, R. 2008. The impact of North Atlantic wind and cyclone trends on European precipitation and significant wave height in the Atlantic. Annals of the New York Academy of Sciences, 1146, 212-234.

Trouet, V., Esper, J., Graham, N. E., Baker, A., Scourse, J. D. \& Frank, D. C. 2009. Persistent positive North Atlantic oscillation mode dominated the medieval climate anomaly. Science, 324, 78-80.

van Heteren, S., Fitzgerald, D. M., McKinlay, P. A \& BUYNeVICH, I. V. 1998. Radar facies of paraglacial barrier systems: coastal New England, USA. Sedimentology, 45, 181-200.
Vis, G.-J., Kasse, C. \& Vandenberghe, J. 2008. Late Pleistocene and Holocene palaeogeography of the Lower Tagus Valley (Portugal): effects of relative sea level, valley morphology and sediment supply. Quaternary Science Reviews, 27, 1682-1709.

Vis, G.-J., Bohncke, S. J. P., Schneider, H., Kasse, C., Coenraads-Nederveen, S., ZuUrbier, K. \& Rozema, J. 2010a. Holocene flooding history of the Lower Tagus Valley (Portugal). Journal of Quaternary Science, 25, 1222-1238.

Vis, G.-J., Kasse, C., Kroon, D., Jung, S., Zuur, H. \& Prick, A. 2010 $b$. Late Holocene sedimentary changes in floodplain and shelf environments of the Tagus River (Portugal). Proceedings of the Geologists Association, 121, 203-217.

Wintle, A. G. \& Murray, A. S. 2006. A review of quartz optically stimulated luminescence characteristics and their relevance in single-aliquot regeneration dating protocols. Radiation Measurements, 41, $369-391$. 